\title{
Pengembangan Tes Berpikir Kreatif terhadap Hasil Belajar Akuntansi Siswa SMA Darussalam Medan
}

\author{
Dewi Wahyuni ${ }^{1}$, Mekar Meilisa Amalia ${ }^{*}$ \\ ${ }^{1}$ Program Studi Akuntasi, Fakultas Ekonomi dan Bisnis, Universitas Dharmawangsa \\ Jl. Yos Sudarso No. 224, Kec. Medan Baru, Kota Medan, Sumatera utara \\ E-mail: *1'mekar.amalia@dharmawangsa.ac.id
}

Received: Februari 2021; Accepted: Mei 2021; Published: Juni 2021

\begin{abstract}
The purpose of this study was to determine the effectiveness of the accounting creative thinking test on the learning outcomes of SMA Darussalam, to determine the sensitivity of the accounting creative thinking test to the learning outcomes of SMA Darussalam and to determine the students' responses to the accounting creative thinking test on the learning outcomes of SMA Darussalam. This research is a research on the development of Sugiono's modification through four stages, namely, test design, validation, limited trials and extensive trials. The instruments used in this study were creative thinking tests, validation sheets and student response questionnaires. The instrument was declared to have met the quality of the test. Testing the quality of the test for creative thinking in accounting by looking at the results of the validity, the distinguishing power of the questions, the difficulty level of the questions and the reliability of the questions. Based on the results of the calculation, it was found that the developed creative thinking test was less effective, because the average value of students' creative thinking skills had not yet reached a value of 60 . The sensitivity of the creative thinking test was sensitive to student accounting learning outcomes with an average of 0.434 . Student response to the creative thinking test developed was negative which was below $80 \%$, which was $71.85 \%$. So it can be concluded that the sensitivity of the accounting creative thinking test and the time it takes to complete the creative thinking test is effective and usable. However, in the creative thinking test category this is not effective because to answer the test requires a sufficiently deep skill, and this has not been mastered by the students.
\end{abstract}

Keywords: Creative Thinking Tests; Accounting.

\begin{abstract}
Abstrak
Tujuan dari penelitian ini adalah untuk mengetahui keefektifan tes berpikir kreatif akuntansi terhadap hasil belajar SMA Darussalam, untuk mengetahui sensitivitas tes berpikir kreatif akuntansi terhadap hasil belajar SMA Darussalam dan untuk mengetahui respon siswa atas tes berpikir kreatif akuntansi terhadap hasil belajar SMA Darussalam. Penelitian ini merupakan penelitian pengembangan modifikasi Sugiono melalui empat tahap, yaitu uji desain, validasi, uji coba terbatas dan uji coba ekstensif. Instrumen yang digunakan dalam penelitian ini adalah tes berpikir kreatif, lembar validasi dan angket respon siswa. Instrumen dinyatakan telah memenuhi kualitas tes. Pengujian kualitas tes berpikir kreatif dalam akuntansi dengan melihat hasil validitas, daya pembeda soal, tingkat kesukaran soal dan reliabilitas soal. Berdasarkan hasil perhitungan diketahui bahwa tes berpikir kreatif yang dikembangkan kurang efektif, karena nilai rata-rata kemampuan berpikir kreatif siswa belum mencapai nilai 60 . Sensitivitas tes berpikir kreatif peka terhadap hasil belajar akuntansi siswa dengan rata-rata sebesar 0,434 . Respon siswa terhadap tes berpikir kreatif yang dikembangkan adalah negatif yaitu dibawah $80 \%$ yaitu $71,85 \%$. Sehingga dapat disimpulkan bahwa sensitivitas tes berpikir kreatif akuntansi dan waktu yang dibutuhkan untuk menyelesaikan tes berpikir kreatif adalah efektif dan bermanfaat. Namun pada kategori tes berpikir kreatif hal ini kurang efektif karena untuk menjawab tes tersebut diperlukan keterampilan yang cukup mendalam, dan hal ini belum dikuasai oleh siswa.
\end{abstract}

Kata Kunci: Tes Berpikir Kreatif; Akuntansi.

doi: https://doi.org/10.51544/jma.v6i1.1453

(C) 2021 Jurnal Mutiara Akuntansi. This is an open access article under the CC BY-SA license

Website: http://e-journal.sari-mutiara.ac.id/index.php/JMA/

http://e-journal.sari-mutiara.ac.id 


\section{PENDAHULUAN}

Pada saat ini kita menghadapi revolusi industri keempat yang dikenal dengan nama Revolusi Industri 4.0. Ini merupakan era inovasi disruptif, dimana inovasi ini berkembang sangat pesat, sehingga mampu membantu terciptanya pasar baru. Banyak hal yang harus diubah oleh negara yang ingin maju. Hal ini juga berlaku bagi Indonesia, dimana saat ini Indonesia dalam menghadapi era Revolusi Industri 4.0 memiliki tingkat persaingan yang semakin ketat. Untuk menghadapi perkembangan Revolusi Industri 4.0 tersebut, diperlukan sumber daya manusia (SDM) yang memiliki kemampuan berpikir logis, bersifat kritis, kreatif, inisiatif dan adaptif terhadap perubahan dan perkembangan. Salah satu SDM yang harus dilatih dalam menghadapi perkembangan Revolusi Industri 4.0 adalah peserta didik khususnya Sekolah Menengah Atas (SMA), sehingga peningkatan kualitas pendidikan perlu mendapat perhatian lebih.

Salah satu kualitas pendidikan yang perlu ditingkatkan adalah tes. Tes adalah alat untuk mengukur kemampuan siswa. Menurut Arikunto (2009), tes adalah merupakan alat atau prosedur yang digunakan untuk mengetahui atau mengukur sesuatu dalam suasana, dengan cara dan aturan-aturan yang sudah ditentukan. Dengan adanya tes, siswa dan guru dapat mengetahui sejauhmana telah berhasil mengikuti pelajaran yang diberikan guru. Oleh sebab itu, tes harus dibuat semenarik mungkin dan dapat menumbuhkan kemampuan siswa untuk mengeluarkan ideide, gagasan kreatif dan cara yang berbeda dari teman yang lainnya dalam menjawab tes tersebut.

Tes berpikir kreatif adalah suatu tes yang digunakan untuk mengukur kemampuan berpikir divergen, dengan membedakan aspek kelancaran, kelenturan, orisionalitas dan kerincian dalam berpikir serta untuk merasakan dan mengamati adanya masalah, membuat dugaan tentang kekurangan (masalah) ini, menilai dan menguji dugaan atau hipotesis, kemudian mengubah dan mengujinya lagi, dan akhirnya menyampaikan hasil-hasilnya.

Namun kenyataannya tidak sesuai dengan harapan, dari hasil wawancara kami dengan beberapa guru akuntasi di SMA Darussalam Medan dinyatakan bahwa soal-soal yang diujikan guru biasanya sama dengan contoh soal yang dijelaskan oleh guru. Contoh tes yang dijelaskan guru dengan tes yang dikerjakan siswa hanya berbeda pada objek dan nilainya saja. Untuk menyelesaikan tes tersebut siswa hanya dituntut prosedur yang rutin. Tes yang disajikan kurang melatih siswa untuk berpikir mengeluarkan ide-ide dan gagasan kreatif. Sehingga menyebabkan siswa menjadi pasif di dalam kelas dan tes tersebut kurang menumbuhkan kemampuan berpikir kreatif siswa dalam proses menjawab tes akuntansi.

Adapun rumusan masalah dalam penelitian ini adalah (1) Bagaimanakan efektifitas tes berpikir kreatif akuntansi yang dikembangkan terhadap hasil belajar siswa? (2) Bagaimanakan sensitivitas tes berpikir kreatif akuntansi yang dikembangkan terhadaphasil belajar siswa? (3) Bagaimana respon siswa terhadap tes berpikir kreatif akuntasi yang dikembangkan terhadap hasil belajar siswa?

Berdasarkan rumusan masalah yang dikemukakan sebelumnya, maka tujuan dalam penelitian adalah (1) Untuk mengetahui efektifitas tes berpikir kreatif akuntansi yangdikembangkan terhadaphasil belajar siswa. (2) Untuk mengetahui sensitivitas tes berpikir kreatif akuntansi yang dikembangkan terhadaphasil belajar siswa. (3) Untuk mengetahui respon siswa terhadap tes berpikir kreatif akuntasi yangdikembangkan terhadap hasil belajar siswa.

Komunikasi pun dianjurkan untuk dilakukan secara daring. Mengutip data dari Asosiasi Penyelenggara Jasa Internet Indonesia (APJII) di situs kominfo.go.id, pengguna internet tahun 2020, meningkat sebesar 25,5 juta atau 8,9\% dibandingkan tahun 2019 (Yusuf, 2020). Peningkatan penggunaan Internet tersebut, berbanding lurus dengan data transasksi ekonomi 
digital yang juga meningkat pesat pada masa pandemi, sebesar 400 persen dan diprediksi meningkat pada masa new normal atau adaptasi kebiasaan baru. Selain marketplace, retailer besar hingga minimarket pun membuka layanan online hingga delivery (Gusti, 2020).

\section{TINJAUAN LITERATUR}

Menurut Arikunto (2009), tes adalah merupakan alat atau prosedur yang digunakan untuk mengetahui atau mengukur sesuatu dalam suasana, dengan cara dan aturan-aturan yang sudah ditentukan. Untuk mengerjakan tes ini tergantung dari petunjuk yang diberikan. Adapun langkah-langkah penyusun tes yang baik menurut Lasiman dkk. (2016) adalah penentuan tujuan tes, penyusunan kisi-kisi tes, penulisan soal, penelaahan soal (validasi soal), perakitan soal menjadi perangkat tes, uji coba soal termasuk analisisnya, bank soal, penyajian tes kepada siswa, skoring (pemeriksaan jawaban siswa). Salah satu langkah yang jarang atau tidak pernah dilakukan guru adalah uji coba dan analisis butir tes.

Menurut Munandar (2010), berpikir kreatif atau berpikir divergen adalah memberikan macam-macam kemungkinan jawaban berdasarkan informasi yang diberikan dengan penekanan pada keragaman jawaban dan kesesuaian. Untuk melatih kemampuan berpikir kreatif, siswa harus dihadapkan dengan permasalahan yang memiliki jawaban yang berbeda. Kemudian, siswa memberikan gagasan atau jawaban yang beranekaragam menurut pemikiran dan kemampuan masing-masing. Apabila berpikir kreatif, siswa selalu dilatih dapat meningkatkan kemampuan siswa dalam menyelesaikan masalah akuntansi (Siswono, 2006). Evans dalam Siswono (2006) menyebutkan bahwa komponen berpikir divergen terdiriatas komponen sensitivity, fluency, flexibility dan originality.

1. Sensitivity (kepekaan).

Kemampuan untuk mengenal adanya suatu masalah dan mengabaikan fakta-fakta yang kurang sesuai (misleading fact) dalam mengenal masalah yang sebenarnya.

2. Fluency (kefasihan atau kelancaran).

Kemampuan dalam membangun ide-ide. Fluency memegang peranan yang penting, karena semakin banyak ide yang didapat, maka peluang untuk mendapat ide yang bagus semakin besar.

3. Flexibility (keluwesan atau kelenturan).

Kemampuan untuk membangun ide-ide yang beragam. Flexibility terkait dengan kemampuan untuk mencoba berbagai pendekatan dalam pemecahan masalah.

4. Originality (keaslian).

Kemampuan untuk menghasilkan ide-ide yang tidak umum atau luar biasa, menyelesaikan masalah dengan cara yang tidak umum, tidak baku atau menggunakan sesuatu atau manfaat situasi dengan cara yang tidak umum.

Menurut Sugiyono (2010), model pengembangan tes berpikir kreatif terdiri dari empat tahapan, sebagai berikut:

\section{Tahapan 1- Investigasi Awal}

Pada tahapan ini yang akan dilaksanakan yaitu:

1. Menganalisis materi yang telah dipilih dan ditetapkan, serta dirincikan dan disusun secara sistematis materi ajar yang relevan untuk dijadikan tes berpikir kreatif berdasarkan yang telah dipelajari siswa,

2. Standar kompetensi (SK),

3. Tes berpikir kreatif harus sesuai karakteristik berpikir kreatif yaitu (berpikir lancar, berpikir luwes, berpikir orisinil dan berpikir elaborasi),

4. Analisis kurikulum yaitu menyusun kompetensi dasar terkait dengan berpikir kreatif siswa. 


\section{Tahapan 2 -Validasi}

1. Validitas isi (content validity) adalah untuk mengukur tujuan khusus yaitu materiajar dengan cara merincikan materi kurikulum atau materi buku pelajaran yangmencakup semua pokok atau sub-pokok bahasan yang hendak diukur

2. Validitas konstan (construct validity) terdiri dari Standar Kompetensi (SK), Kompetensi Dasar (KD), Indikator Pencapaian, dan Materi pokok.

\section{Tahapan 3 - Uji Coba Terbatas}

Pada tahapan ini dilakukan uji coba desain tes berpikir kreatif akuntansi secara terbatas untuk meperoleh masukan berupa saran untuk perbaikan materi untuk direvisi agar menghasilkan tes berpikir kreatif yang baik.

\section{Tahapan-4 Uji Coba Lebih Luas}

Dari hasil ujicoba ini dianalisis kemudian direvisi untuk mendapat tes berpikir kreatif materi final (Draft Final). Menurut Sinaga (2007):

1. Hasil analis menunjukkan bahwa tes berpikir kreatif yang telah dikembangkan sudah valid dan layak digunakan tanpa revisi. Jika demikian, tes berpikir kreatif tersebut dapat diujicobakan secara luas di lapangan.

2. Hasil analisis menunjukkan bahwa tes berpikir kreatif yang telah diujicobakansecara terbatas sudah valid dan layak digunakan dengan syarat disempurnakanatau direvisi. Jika demikian, dilakukan revisi atau penyempurnaan terhadap tes berpikir kreatif tersebut dan hasil revisi atau penyempurnaan siap diujicobakan kembali secara luas di lapangan.

3. Hasil analisis menunjukkan bahwa tes berpikir kreatif yang telah diujicobakan tidak valid dan tidak layak digunakan. Jika demikian, dilakukan revisi besarterhadap tes berpikir kreatif tersebut menurut masukan para ahli

4. Indikator keberhasilan pengembangan tes berpikir kreatif adalah terdapat vadilitas, reliabilitas, daya beda, tingkat kesukaran tehadap tes.

Adapun kualitas perangkat pembelajaran dapat dibagi menjadi tiga yaitu:

\section{Validitas}

Validitas merupakan suatu standar atau dasar ukuran yang menunjukkan ketetapan (appropriateness), kemanfaatan (userfulness) dan kesahihan yang mengarah pada ketepatan interpretasi suatu prosedur evaluasi sesuai dengan tujuan pengukurannya.

2. Sensitivitas

Sensitivitas digunakan untuk mengetahui efek (pengaruh) dari suatu pembelajaran. Indeks sensitivitas dari suatu butir soal merupakan ukuran beberapa baik butir soal membedakan antara siswa yang telah menerima pembelajaran dengan siswa yang belum menerima pembelajaran.

3. Efektivitas

Menurut Sudjana (1990), efektivitas dapat diartikan sebagai tindakan keberhasilan siswa untuk mencapai tujuan tertentu yang dapat membawa hasil belajar secara maksimal.

\section{METODE PENELITIAN}

Penelitian ini dikategorikan kedalam penelitian pengembangan (Research and Development) dengan menggunakan model pengembangan Sugiyono yang dimodifikasi, yaitu Tahapan 1- Investigasi Awal, Tahapan 2- Validasi, Tahapan 3 - Uji Coba Terbatas dan Tahapan 4- Uji Coba Lebih Luas. Dalam penelitian ini yang akan dikembangkan adalah tes berpikir kreatif akuntansi.

Penelitian ini dilakukan di SMA Darussalam Medan Tahun Ajaran 2019/2020 dimana pelaksanaan penyebaran tes berpikir kreatif akuntasi dilakukan sebanyak tiga kali. 
Subjek dalam penelitian ini adalah siswa kelas XII IPA dan siswa kelas XII IPS SMA Darussalam Medan pada Tahun Ajaran 2019/2020. Objek dalam penelitian ini adalah tes berpikir kreatif akuntansi.

Prosedur dalam penelitian ini adalah pengembangan tes berpikir kreatif akuntansi yang dikembangkan menggunakan metode pengembangan Sugiono yang telah dimodifikasi. Pengembangan tes berpikir kreatif akuntansi ini melalui empat tahapan yaitu tahapan ke 1 investigasi awal yaitu menganalisis dan merancang tes berpikir kreatif akuntansi yang sesuai dengan kemampuan siswa-siswi SMA Darussalam, tahapan ke 2 yaitu validitas yaitu memvalidasi tes berpikir kreatif akuntasi, tahapanke 3 uji coba terbatas yaitu tes diuji coba secara terbatas, dan tahapan ke 4 uji coba lebih luas yaitu di tahapan ini akan didapat tes berpikir kreatif final. Pengembangan tes berpikir kreatif akuntansi dalam penelitian ini secara skematis digambarkan pada gambar 1 .

Instrumen dalam penelitian ini dapat diuraikan dibawah ini:

\section{Lembar Validasi}

Lembar validasi dalam penelitian ini digunakan untuk mengukur kevalidan tes berpikir kreatif akuntansi yang efektif dan sensitivitas tes hadap tes yang berbentuk tes uraian yang disusun sesuai dengan kurikulum pelajaran akuntansi dan memiliki indikator berpikir kreatif yaitu berpikir lancar, berpikir luwes, berpikir orisinil dan berpikir elaborasi. Lembar validasi ini digunakan untuk mendapat data dari para ahli (validator) terhadap tes berpikir kreatif akuntansi dalam merevisi tes berpikir kreatif akuntasi yang telah disusun dan selanjutnya tes dianalis dengan memvaliditas tes, reliabilitas tes, daya beda dan tingkat kesukaran tes. Apabila tes telah divalidasi, dicari reliabilitas, daya beda dan tingkat kesukaran tes maka tes tersebut berkualitas.

\section{Angket}

Angket respon siswa terhadap tes berpikir kreatif akuntansi diperoleh setelah berakhirnya seluruh proses pembelajaran dan uji coba lapangan, dengan menggunakan angket respon siswa.

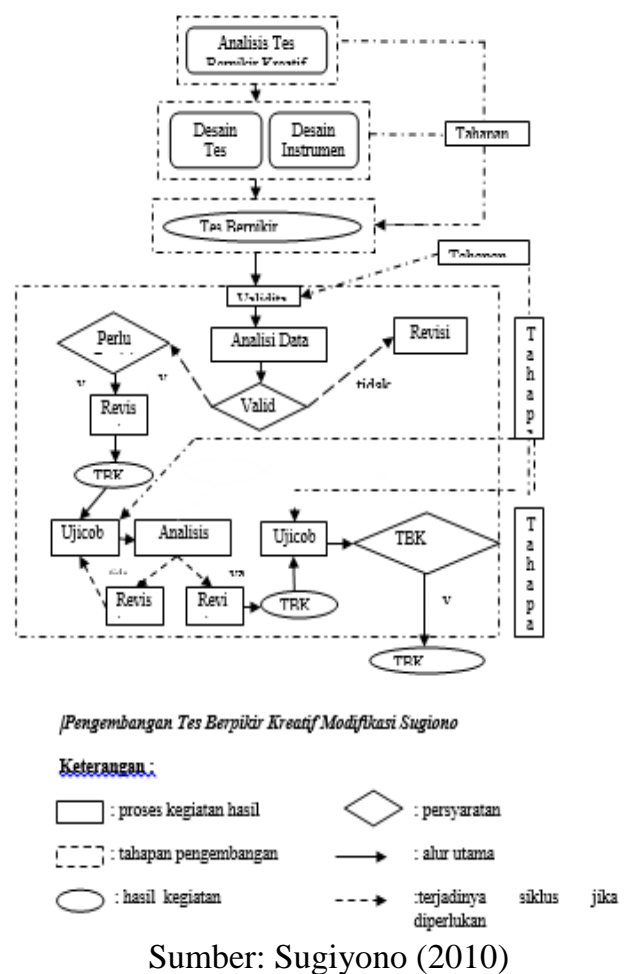

Gambar 1. Pengembangan Tes Berpikir Kreatif Modifikasi Sugiyono 
Teknik analisis data yang digunakan adalah:

1. Validasi Ahli

Kegiatan analisis kevalidan tes berpikir kreatif yang digunakan dalam penelitian ini mengikuti langkah-langkah yang dinyatakan Horbi (2010) yaitu:

a. Melakukan rekapitulasi data penelitian kevalidan perangkat tes ke dalam tabel yang meliputi: aspek $(A i)$, indikator ( $I i)$, dan nilai ( ) untuk masing-masing indikator.

b. Menentukan rata-rata nilai hasil validasi dari semua validator untuk indikator.

c. Menentukan rerataan nilai untuk setiap aspek.

d. Menentukan nilai $V a$ atau nilai rerataan total dari rerataan nilai untuk setiapaspek.

Tabel 1. Kriteria Validasi Para Ahli

\begin{tabular}{cc}
\hline Kriteria & Deskripsi \\
\hline $1 \leq V a<2$ & Tidak Valid \\
$2 \leq V a<3$ & Kurang Valid \\
$3 \leq V a<4$ & Cukup Valid \\
$4 \leq V a<5$ & Valid \\
$V a=5$ & Sangat Valid \\
\hline \multicolumn{2}{r}{ Sumber: Horbi (2010) }
\end{tabular}

Menurut Sinaga (2007), dari hasil validasi yang diperoleh dari para ahli dapat diklasifikasi dalam tiga kemungkinan, yaitu:

a. Apabila hasil analisis data validasi menunjukkan bahwa Prototipe-1 (tes berpikir kreatif) adalah valid dan layak tanpa revisi, maka tes berpikir berpikir kreatif siap untuk diujicoba di lapangan (pemberian tes berpikir kreatif dalam kelas)

b. Apabila hasil analis data validasi menunjukkan bahwa Prototipe-1 (tes berpikir kreatif) adalah valid dan layak digunakan dengan revisi kecil dan dilakukan revisi kecil pada tes berpikir kreatif. Prototipe-1 (tes berpikir kreatif) yang sudah direvisi di sebut Prototipe-2 dan siap untuk diujicobakan di lapangan.

c. Apabila hasil analisis data validasi menunjukkan Prototipe-1 (tes berpikir kreatif) adalah tidak valid atau tidak layak, maka dilakukan revisi besar. Hasil revisi Prototipe-1 (tes berpikir kreatif) harus divalidasi kembali oleh para ahli. Kegiatan menvalidasi ini dimungkinkan terjadi siklus (kegiatan validasi secara berulang) sampai diperoleh Prototipe (tes berpikir kreatif) yang memenuhi kreteria kevalidan. Prototipe (tes berpikir kreatif) yang memenuhi kreteria kevalidan selanjutnya disebut Prototipe-2 dan siap untuk diujicobakan di lapangan.

\section{Validitas Tes Berpikir Kreatif}

Validitas konstruksi butir soal dari suatu tes adalah ketepatan mengukur yang dimiliki oleh sebutir soal, dalam mengukur apa yang seharusnya diukur lewat butir soal tersebut. Sebuah butir soal dikatakan valid bila mempunyai dukungan yang besar terhadap skor total.

Menurut Arikunto (2009), untuk menguji validitas tes digunakan rumus:

$$
r_{x y}=\frac{N \sum X Y-\left(\sum X\right)\left(\sum Y\right)}{\sqrt{\left.\left\{N \sum X^{2}-\left(\sum X\right)^{2}\right\}, N \sum Y^{2}-\left(\sum Y\right)^{2}\right\}}}
$$

Keterangan :

$\mathrm{X}=$ Butir tes berpikir kreatif.

$\mathrm{Y}=$ Jumlah total tes berpikir kreatif.

${ }^{\mathrm{r}} \mathrm{XY}=$ Koefisien korelasi antara variabel $\mathrm{X}$ dan varibel $\mathrm{Y}$, dua variabel yang dikorelasikan

Selanjutnya diuji dengan menggunakan uji-t, dengan rumus:

$$
t=r_{x y} \sqrt{\frac{N-2}{1-\left(r_{x y}\right)^{2}}}
$$


Menentukan validitas suatu butir soal. Kriteria yang harus dipenuhi agar suatu butir soal dikatakan valid adalah jika $t_{\text {hitung }}>t_{\text {tabel }}$ dengan $\quad t_{\text {tabel }}=t_{(1-\alpha)(d k)}$ untuk dk $=N-2$ dan $\alpha$ (taraf signifikansi) dipilih $5 \%$.

Arikunto (2009) menyatakan bahwa untuk menginterpretasikan koefisien reliabilitas suatu alat evaluasi interpretasi dari koefisien korelasi digunakan kriteria sebagai berikut:

Koefisien korelasi selalu terdapat antara $-1,00$ sampai $+1,00$. Koefisien negatif menunjukkan hubungan kebalikan sedangkan koefisien positif menunjukkan adanya kesejajaran untuk mengadakan interpertasi mengenai besarnya koefisien korelasi adalah sebagai berikut:

a. Koefisien korelasi selalu terdapat antara $-1,00$ sampai $+1,00$. Koefisien negatif menunjukkan hubungan kebalikan sedangkan koefisien positif menunjukkan adanya kesejajaran untuk mengadakan interpertasi mengenai besarnya koefisien korelasi adalah sebagai berikut:

Tabel 2. Validasi Tes Berpikir Kreatif

\begin{tabular}{clc}
\hline \multicolumn{1}{c}{ Kriteria } & \multicolumn{2}{c}{ Deskripsi } \\
\hline $0,80<\mathrm{r}_{\mathrm{xy}} \leq 1,00$ & $\begin{array}{l}\text { validitas } \\
\text { tinggi }(S T)\end{array}$ & sangat \\
$0,60<\mathrm{r}_{\mathrm{xy}} \leq 0,80$ & $\begin{array}{l}\text { validitas } \\
(T G)\end{array}$ & tinggi \\
$0,40<\mathrm{r}_{\mathrm{xy}} \leq 0,60$ & $\begin{array}{l}\text { validitas } \\
(S D)\end{array}$ & sedang \\
$0,20<\mathrm{r}_{\mathrm{xy}} \leq 0,40$ & $\begin{array}{l}\text { validitas } \\
(R D)\end{array}$ & rendah \\
& $\begin{array}{l}\text { validitas } \\
\text { rendah }(S R)\end{array}$ & sangat \\
$0,00<\mathrm{r}_{\mathrm{xy}} \leq 0,20$ & \multicolumn{3}{c}{ Sumber: Arikunto (2009) }
\end{tabular}

b. Dengan berkonsultasi ke tabel harga kritis $r$ produk moment, jika harga $r$ lebih kecil dari harga kritis dalam tabel, maka korelasi tersebut tidak signifikan (TDK). Jika harga $r$ lebih besar dari harga kitis dalam tabel, maka korelasi tersebut signifikan $(S I G)$.

3. Analisis Tingkat Kesukaran

Arikunto (2009) menyatakan rumus untuk menganalisis tingkat kesukaran sebagai berikut:

$$
I=\frac{B}{N}
$$

Keterangan :

$\mathrm{I}=$ Indeks kesukaran

$\mathrm{B}=$ Jumlah Skor

$\mathrm{N}=$ Jumlah skor ideal pada setiap soal tersebut

Interpretasi indeks kesukaran digunakan kriteria sebagai berikut:

Tabel 3. Kriteria Tingkat Kesukaran

\begin{tabular}{cc}
\hline Kriteria & Deskripsi \\
\hline TK $=0,00$ & Terlalu Sukar (TS) \\
$0,00<T K \leq 0,3$ & Sukar (SK) \\
\hline
\end{tabular}




\begin{tabular}{cc}
$0,3<T K \leq 0,7$ & Sedang (SD) \\
$0,7<T K \leq 1$ & Mudah (MD) \\
TK $=1$ & Terlalu Mudah (TM) \\
\hline Sumber: Arikunto (2009)
\end{tabular}

4. Analisis Data Daya Pembeda

Daya pembeda soal adalah kemampuan suatu soal untuk membedakan antara siswa yang kurang pandai dengan siswa yang pandai (Arikunto, 2009) yaitu:

$\mathrm{DP}=$ Daya pembeda

$$
D P=\frac{S A-S B}{I A}
$$

$\mathrm{SA}=$ Jumlah skor kelompok atas pada butir soal yang diolah

$\mathrm{SB}=$ Jumlah skor kelompok bawah pada butir soal yang diolah

IA = Jumlah skor ideal salah satu kelompok butir soal dipilih

Kriteria tingkat daya pembeda menurut Arikunto(2009) adalah sebagai berikut:

Tabel 4. Kriteria Tingkat Daya Pembeda

\begin{tabular}{ll}
\hline \multicolumn{1}{c}{ Kriteria } & \multicolumn{1}{c}{ Deskripsi } \\
\hline Negatif $-9 \%$ & Sangat jelek \\
$10 \%-19 \%$ & Jelek \\
$20 \%-29 \%$ & Cukup \\
$30 \%-49 \%$ & Baik \\
$50 \%-$ Ke atas & Sangat baik \\
\hline \multicolumn{2}{c}{ Sumber: Arikunto (2009) }
\end{tabular}

5. Analisis Data Reliabilitas

Reliabilitas tes digunakan untuk melihat kesejajaran hasil yang diperoleh walaupun dilakukan pengukuran kembali terhadap subjek yang sama. Reliabilitas tes diuji dengan menggunakan rumus yang berasal dari Arikunto (2009):

Rumus alpha-cronbach: $\quad r_{11}=\left(\frac{n}{n-1}\right)\left(1-\frac{\sum \sigma_{i}^{2}}{\sigma_{t}^{2}}\right)$

$\mathrm{n} \quad$ = banyak soal

$\sigma_{i}^{2}=$ variansi item

$\sigma_{t}^{2}=$ variansi total

Hasil perhitungan koefisien reliabilitas, kemudian ditafsirkan dan diinterpretasikan mengikuti interpretasi menurut Arikunto (2009), yaitu:

Tabel 5. Kriteria Data Reliabilitas

\begin{aligned} & \hline \multicolumn{1}{c}{ Kriteria } \multicolumn{1}{c}{ Deskripsi } \\ & \hline $0,80<\mathrm{r} \leq 1,00$ Sangat Tinggi $(S T) \\ & 0,60<\mathrm{r} \leq 0,80$ Tinggi $(T G) \\ & \\ &$\hline\end{aligned}




\begin{tabular}{lr}
\hline $0,40<\mathrm{r} \leq 0,60$ & Sedang $(S D)$ \\
$0,20<\mathrm{r} \leq 0,40$ & Rendah $(R D)$ \\
$\mathrm{r} \leq 0,20$ & Sangat Rendah (SR) \\
\hline \multicolumn{2}{c}{ Sumber: Arikunto (2009) }
\end{tabular}

\section{Analisis Data Keefektifan Tes Berpikir Kreatif Akuntansi}

Tes hasil belajar digunakan untuk mendapat keefektivan tes. Menurut Sudjana (1990), interval skor penentuan tingkat kemampuan siswa dikategorikan sebagai berikut:

Tabel 6. Kriteria Keefektifan Tes Berpikir Kreatif

\begin{tabular}{cl}
\hline Rentang Skor & \multicolumn{1}{c}{ Kategori } \\
\hline$r i>80$ & Sangat baik \\
$60<r i \leq 80$ & Baik \\
$40<r i \leq 60$ & Cukup \\
$20<r i \leq 40$ & Kurang \\
$r i \leq 20$ & Sangat Kurang \\
\hline
\end{tabular}

Sumber: Sudjana (1990)

Dalam penelitian ini, tes dikatakan efektif jika persentase ketuntasan belajar klasikal tes hasil belajar peserta didik mencapai klasikal baik. Pembelajaran dikatakan berhasil jika minimal $85 \%$ siswa berada pada katagori minimal baik.

\section{Analisis Data Sensitivitas Tes Berpikir Kreatif Akuntansi}

Sensitivitas digunakan untuk mengetahui efek (pengaruh) dari suatu pembelajaran. Indeks sensitivitas dari suatu butir soal merupakan ukuran beberapa baik butir soal membedakan antara siswa yang telah menerima pembelajaran dengan siswa yang belum menerima pembelajaran. Untuk menghitung sensitivitas butir soal digunakan rumus yang berasal dari Aiken dalam Trianto (2010) sebagai berikut:

$$
\mathrm{S}=\frac{\mathrm{Ra}-\mathrm{Rb}}{\mathrm{T}}
$$

S : Indeks sensitivitas butir soal

Ra: Jumlah siswa yang menjawab benar pada tes akhir $\mathrm{Rb}$ : Jumlah siswa yang menjawab benar pada tes awal $\mathrm{T}$ : Jumlah siswa yang mengikuti tes

Menurut Gronlund dalam Trianto (2010), butir soal dikatakan baik jika sensivitas butir soal berada antara 0,00 dan 1,00 dan nilai positif yang lebih besar menyatakan butir soal yang lebih kepekaannya terhadap efek-efek pembelajaran. Menurut Aiken dalam Trianto (2010), butir soal yang mempunyai sentivitas $\geq 0,30$, maka butir soal tersebut peka terhadap efek-efek pembelajaran. Sehingga dalam penelitian ini, butir soal yang dianggap layak digunakan untuk menilai kualitas kemampuan belajar siswa adalah butir soal yang mempunyai sentivitas $\geq 0,30$.

Jika suatu butir soal dijawab benar oleh semua siswa sebelum dan sesudah pembelajaran, maka butir soal tersebut tidak mengukur efek-efek pembelajaran. Sebaliknya, jika suatu butir soal tidak dapat dijawab benar oleh semua siswa sebelum dan sesuadah pembelajaran, maka soal itu tidak memenuhi fungsinya. Untuk mengetahui sentivitas butir soal, uji awal dan uji akhir 
yang sama harus diberikan kepada siswa. Butir soal yang sentivitas dijawab oleh lebih banyak siswa setelah pembelajaran berlangsung. Nilai positif yang semakin besar menunjukkan bahwa kepekaan butir soal terhadap efek-efek pembelajaran semakin besar.

8. Analisis Data Respon siswa

Data respon siswa dianalisis dengan menghitung persentase respon positif tiap aspek. Persentase tiap respon positif dengan rumus yang berasal dari Trianto (2010):

$$
\text { Pesentase respon siswa }=\frac{A}{B} X 100 \%
$$

Keterangan:

$\mathrm{A}=$ Proposi siswa yang memilih

$\mathrm{B}=$ Jumlah siswa

Adapun kriteria respon siswa dapat dilihat pada tabel berikut:

Tabel 7. Kriteria Respon Siswa

\begin{tabular}{cl}
\hline Respon & Kriteria \\
\hline $80 \%<P R S \leq 100 \%$ & Sangat positif \\
$60 \%<P R S \leq 80 \%$ & Positif \\
$40 \%<P R S \leq 60 \%$ & Cukup \\
$20 \%<P R S \leq 40 \%$ & Kurang \\
$0 \%<P R S \leq 20 \%$ & Rendah \\
\hline \multicolumn{2}{c}{ Sumber: Trianto $(2010)$}
\end{tabular}

Jika $80 \%$ atau lebih siswa merespon maka termasuk kedalam kategori positif untuk setiap aspek yang direspon.

\section{HASIL DAN PEMBAHASAN}

Produk hasil penelitian ini adalah tes berpikir kreatif akuntansi yang efektif dan sensitif. Dalam proses pengembangan untuk mendapatkan tes berpikir kreatif yang efektif dan sensitif, maka telah dilakukan kegiatan mendesain tes berpikir kreatif, validasi tes, uji coba terbatas, dan uji coba lebih luas.

\section{Tahapan-1 Investigasi Awal Pengembangan Tes Berpikir Kreatif}

Pada tahapan ini kami dari tim peneliti merancang tes berpikir kreatif akuntansi yang sesuai dengan materi pembelajaran akuntansi yang telah dipelajari oleh siswa-siswi SMA Darussalam dan dirancang sesuai dengan krakteristik berpikir kreatif yaitu: kepekaan, luwes (banyak jawaban), asli dan terperinci. Tes disusun dengan bentuk uraian agar siswa yang dapat menjawab tes tersebut dengan leluasa tanpa ada batasan sehinggga dapat mengeluarkan ide-ide gagasan yang luas sehingga dapat menumbuhkan berpikir kreatif siswa. Dalam perumusan tes berpikir kreatif meliputi: (1) kisi-kisi tes berpikir kreatif lancar, luwes (banyak jawaban), asli dan terperinci), (2) butir tes berpikir kreatif, (3) kunci jawaban, (4) pedoman penskoran.

Tahapan-2 Validasi tes berpikir kreatif

Setelah tes didesain sesuai dengan krakteristik berpikir kreatif akuntansi dan sesuai dengan materi pembelajaran akuntansi di SMA Darussalam sehingga diproleh draft tes berpikir kreatif akuntansi. Draft tersebut kemudian divalidasi oleh para ahli yang bertujuan untuk melihat 
sejauhmana tes tersebut dapat meningkatkan berpikir kreatif. Validasi para ahli difokuskan pada format, isi, bahasa yang mencakup tes berpikir kreatif akuntansi yang dikembangkan. Tes berpikir kreatif akuntansi ini divalidasi oleh 3 (tiga) orang validator. Ketiga validator terdiri dari 2 (dua) orang dosen akuntansi Universitas Dharmawangsa dan 1 (satu) orangguru SMA Darussalam mata pelajaran akuntansi. Rincian namanya sebagai berikut:

Tabel 8. Data Validator

\begin{tabular}{llll}
\hline No & \multicolumn{1}{c}{$\begin{array}{c}\text { Nama } \\
\text { Validator }\end{array}$} & Jabatan & \multicolumn{1}{c}{ Istitusi } \\
\hline 1. & $\begin{array}{l}\text { Umar } \\
\text { Hamdan } \\
\text { Nasution, }\end{array}$ & Dosen & $\begin{array}{l}\text { Universitas } \\
\text { Dharmawangsa }\end{array}$ \\
& SE.,MM & & \\
2. & Alfirah, & Dosen & Universitas \\
& SE.,M.Si & & Dharmawangsa \\
3. & Nani & Guru & SMA \\
& $\begin{array}{l}\text { Apriani, } \\
\text { S.Pd. }\end{array}$ & \\
\hline \multicolumn{3}{c}{ Sumber: Validasi Ahli (2020) }
\end{tabular}

Hasil validasi didapat berupa koreksi, kritik, masukan dan saran yang digunakan untuk melakukan revisi dan penyempurnaan terhadap perangkat pembelajaran yang dikembangkan. Dalam melakukan revisi, peneliti mengacu pada hasil diskusi dengan mengikuti saran-saran dan petunjuk validator. Hasil validasi ahli terhadap perangkat pembelajaran yang dikembangkan disajikan dalam tabel berikut ini:

Tabel 9 Hasil Validasi Para Validator

\begin{tabular}{clll}
\hline No & $\begin{array}{c}\text { Nama } \\
\text { Validator }\end{array}$ & Kesalahan & \multicolumn{1}{c}{ Revisi } \\
\hline 1. & $\begin{array}{l}\text { Umar } \\
\text { Hamdan } \\
\text { Nasution, } \\
\text { SE.,MM }\end{array}$ & $\begin{array}{l}\text { Kolom soal } \\
\text { pada nomor } \\
\text { 4 pada tes } \\
\text { berpikir } \\
\text { kreatif } \\
\text { akuntansi } \\
\text { kurang lebar. }\end{array}$ & $\begin{array}{l}\text { Kolom soal } \\
\text { nomor 4 } \\
\text { diperbaiki } \\
\text { dengan } \\
\text { memperbesar } \\
\text { kolom }\end{array}$ \\
& & Valid & Valid \\
2. & $\begin{array}{l}\text { Alfirah, } \\
\text { SE.,M.Si }\end{array}$ & Soal pada \\
Nina & $\begin{array}{l}\text { Soal pada } \\
\text { nomor 1 } \\
\text { Apriani }\end{array}$ & $\begin{array}{l}\text { nomor 1 } \\
\text { belum } \\
\text { dipelajari }\end{array}$ & $\begin{array}{l}\text { dengan } \\
\text { pelajaran yang } \\
\text { telah di }\end{array}$ \\
& S. Pd & ajarkan guru. \\
\hline
\end{tabular}

Sumber: Lembar Hasil Validasi (2020)

Berdasarkan hasil perhitungan lembar validasi yang diberikan para validator diperoleh hasil validasi tes berpikir akuntansi yang dikembangkan sebesar $\mathrm{V}_{\mathrm{a}}=4.89$ dengan kriteria valid. Dari segi tata bahasa (pemilihan kata), perbaikan langsung dilakukan pada kotak soal dan soal nomor satu yang belum dipelajari dengan mempertimbangkan masukan para validator untuk menyempurnakan tes berpikir kreatif akuntansi yang sedang dikembangkan.

Berdasarkan data hasil validasi isi tes berpikir kreatif yang diberikan oleh para validator, disimpulkan bahwa hasil analisis data validasi menunjukkan bahwa Prototipe-1 (tes berpikir kreatif) adalah valid dan layak digunakan dengan revisi kecil dan dilakukan revisi kecil pada tes berpikir kreatif. Prototipe-1 (tes berpikir kreatif) yang sudah direvisi disebut Prototipe-2 dan siap 
untuk diujicobakan di lapangan dan dapat digunakan untuk mengukur berpikir kreatif siswa mata pelajaran akuntansi.

\section{Tahapan-3 Uji Coba Terbatas.}

Ujicoba tes kemampuan siswa berpikir kreatif bertujuan untuk mendapat data mengenai validitas butir tes, reliabilitas tes, tingkat kesukaran, daya pembeda dan sensitivitas butir tes. Kelima indikator ini akan menentukan tes yang telah dikembangkan dapat diujicobakan lebih luas atau tes yang telah dikembangkan direvisi kembali. Pada tahapan uji coba terbatas ini dibagi menjadi 5 (lima) langkah:

a. Validitas Tes Berpikir Kreatif

Berdasarkan hasil pengujian validitas soal tes berpikir kreatif akuntansi diperoleh nlai koefisien validasi masing-masing soal tes berpikir kreatif akuntansi akan disajikan pada tabel 10 . Kriteria pengujian yaitu nilai $r_{x y}$ dibandingkan dengan nilai $r$ tabel, jika nilai $r_{x y}>r_{\text {tabel }}$ maka soal tersebut valid dan dapat digunakan sebagai soal tes berpikir kreatif akuntansi.

Tabel 10. Hasil Uji Validitas Tes Berpikir Kreatif Akuntansi

\begin{tabular}{ccccc}
\hline Nomor Soal & Nilai $\mathrm{r}_{\mathrm{xy}}$ & Kriteria & $\mathrm{r}_{\text {tabel }}$ & Keterangan \\
\hline 1 & 0,931 & Tinggi & 0,404 & Valid \\
2 & 0,973 & Tinggi & 0,404 & Valid \\
3 & 0,979 & Tinggi & 0,404 & Valid \\
4 & 0,962 & Tinngi & 0,404 & Valid \\
\hline \multicolumn{5}{r}{ Sumber: Data diolah (2020) }
\end{tabular}

Berdasarkan hasil perhitungan menggunakan SPSS versi 23, tes berpikir kreatif akuntansi yang dikembangkan dengan jumlah responden sebanyak 26 orang pada kelas IPS untuk setiap butir soal tes berpikir kreatif akuntansi lebih besar nilai $r_{\text {tabel }}$, maka dapat disimpulkan bahwa tes berpikir kreatif akuntansi memiliki kevalidan yang cukup tinggi sehingga tes berpikir kreatif akuntasi dapat dipergunakan untuk mengukur kemampuan berpikir kreatif siswa dan dapat diujicobakan secara luas.

b. Tingkat Kesukaran

Setelah diperoleh hasil perhitungan validasi tes selanjutnya menghitung tingkat kesukaran. Adapun tingkatkesukaran soal yaitu:

Tabel 11. Hasil Uji Tingkat Kesukaran Tes Berpikir Kreatif Akuntansi

\begin{tabular}{ccccc}
\hline $\begin{array}{c}\text { Aspek yang } \\
\text { dinilai }\end{array}$ & Butir 1 & Butir 2 & Butir 3 & Butir 4 \\
\hline $\begin{array}{c}\text { Indeks } \\
\text { Interpretasi }\end{array}$ & 0.538 & 0.403 & 0.278 & 0.202 \\
& Sedang & Sedang & Sukar & Sukar \\
\hline \multicolumn{5}{c}{ Sumber: Data diolah (2020) }
\end{tabular}

Berdasarkan hasil uji tingkat kesukaran diperoleh soal tes berpikir kreatif pada soal nomor satu dan soal nomor dua memiliki tingkat kesukaran pada kategori sedang dan soal nomor tiga dan empat memiliki tingkat kesukaran pada kategori sukar.

c. Daya Pembeda

Tabel 12. Daya Pembeda Soal Tes Berpikir Kreatif Akuntansi

\begin{tabular}{lcccc}
\hline \multicolumn{1}{c}{$\begin{array}{c}\text { Aspek yang } \\
\text { Dinilai }\end{array}$} & Soal 1 & Soal 2 & Soal 3 & Soal 4 \\
\hline $\begin{array}{l}\text { Skor Maks } \\
\begin{array}{l}\text { Ideal } \\
\text { Rata-rata Skor }\end{array}\end{array}$ & 3 & 4 & 4 & 4 \\
$\begin{array}{l}\text { Kelompok } \\
\text { Atas }\end{array}$ & 2.692 & 3.231 & 2.615 & 2.307 \\
\hline
\end{tabular}




\begin{tabular}{lcccc}
\hline $\begin{array}{l}\text { Rata-rata Skor } \\
\text { Kelompok }\end{array}$ & & & & \\
Bawah & 1.231 & 0.923 & 0.538 & 0.230 \\
Indeks & 0.487 & 0.576 & 0.519 & 0.519 \\
Interpretasi & Baik & $\begin{array}{c}\text { Sangat } \\
\text { Baik }\end{array}$ & $\begin{array}{c}\text { Sangat } \\
\text { Baik }\end{array}$ & $\begin{array}{c}\text { Sangat } \\
\text { Baik }\end{array}$ \\
\hline
\end{tabular}

Sumber: Data diolah (2020)

Berdasarkan hasil perhitungan daya pembeda soal tes berpikir kreatif akuntansi, diperoleh daya beda pada soal nomor satu sebesar 0,487 dengan kategori baik, selanjutnya pada soal nomor 2,3 dan 4 memiliki daya beda berturut-turut sebesar 0,576, 0,519 dan 0,519 yang artinya daya beda pada soal tes berpkir kreatif akuntansi dalam kategori sangat baik.

d. Reliabilitas

Kriteria pengujian reliabilas soal tes berpikir kreatif dilihat dari nilai Cronbach's Alpha. Jika nilai Alpha > 0,70, maka kontruksi pertanyaan yang merupakan variabel adalah reliabel.

Tabel 13. Uji Reliabilitas Tes Berpikir Kreatif Akuntansi

Reliability Statistics

\begin{tabular}{cc}
\hline Cronbach's Alpha & N of Items \\
\hline, 967 & 4 \\
\hline Sumber: Data diolah $(2020)$
\end{tabular}

Dari hasil perhitungan dengan menggunakan SPSS versi23 diperoleh nilai reliabilitas soal tes berikir kreatif sebesar 0,967 yang artinya nilai alpha > nilai 0,70 atau $0.967>0,70$. Dapat disimpulkan bahwa reliabel tes masuk dalam kriteria sangat tinggi.

e. Sensivitas Tes Berpikir Kreatif

Sensivitas tes berpikir kreatif digunakan untuk melihat kepekaan tes butir soal tersebut peka terhadap efek-efek pembelajaran, butir soal yang dianggap layak digunakan untuk menilai kualitas hasil belajar siswa. Nilai positif yang semakin besar menunjukkan bahwa kepekaan butir soal terhadap efek-efek pembelajaran semakin besar.

Tabel 14. Sensitivitas Tes Berpikir Kreatif

\begin{tabular}{ccccc}
\hline $\begin{array}{c}\text { Aspek } \\
\text { yang } \\
\text { dinilai }\end{array}$ & Butir 1 & Butir 2 & Butir 3 & Butir 4 \\
\hline Indeks & 0.307 & 0.038 & 0.269 & 0.461 \\
Interpretasi & Peka & $\begin{array}{c}\text { Tidak } \\
\text { Peka }\end{array}$ & $\begin{array}{c}\text { Tidak } \\
\text { Peka }\end{array}$ & Peka \\
\hline & & Sumber: & & \\
\hline
\end{tabular}

Sumber: Data diolah (2020)

Suatu butir tes peka terhadap pembelajaran adalah dengan kriteria $S \geq 0.30$. Berdasarkan hasil perhitungan uji coba yang telah dilaksanakan, tes berpikir kreatif yang dikembangkan memiliki hasil sensitivitas pada nomor 1 dan 4 sebesar 0,307 dan 0,461 dengan kategori peka terhadap tes berpikir kreatif akuntansi. Selanjutnya soal tes pada nomor 2 dan 3 memiliki nilai sensitivitas sebesar 0,038 dan 0,2669 dengan kategori tidak peka terhadap tes berpikir kreatif akuntansi.

Berdasarkan hasil ujicoba terbatas, maka dapat disimpulkan tes berpikir kreatif akuntansi yang dikembangkan dapat diujicobakan secara luas sesuai pendapat Sinaga (2007) sehingga dengan demikian, semua butir tes yang telah diujicobakan dapat dikatakan baik sehingga layak untuk digunakan tanpa revisi.

f. Hasil Lembar Observasi Respon Siswa Terhadap Keterbacaan Tes Berpikir Kreatif.

Respon siswa terhadap lembar observasi tes berpikir kreatif sangat penting untuk melihat sejauh mana keterbacaan tes berpikir kreatif yang dikembangkan berhasil atau tidak berhasil. Data hasil respon siswa terhap tes berpikir kreatif dapat dilihat pada tabel 15. 
Hasil pengukuran data respon siswa terhadap tes berpikir kreatif menunjukkan nilai sebesar 77.89\%, 39.74\%, 28.85\% dan 53.85\% dengan kategori kepekaan tes positif, kategori tes dan tes berpiki kreatif kurang baik dan waktu penyelesaian tes sangat cukup baik.

Dari tabel tersebut dapat dijelaskan bahwa soal tes berpikir kreatif akuntansi yang dikembangkan telah sesuai dengan materi yang telah dipelajari siswa, hal ini dapat dilihat dari kuesioner yang telah dibagikan oleh peneliti dimana semua siswa merespon tes berpikir kreatif yang telah dikembangkan sesuai dengan materi pelajaran di SMA Darussalam. Selain materi yang telah sesuai dengan tes berpikir kreatif, bahasa yang digunakan pada tes berpikir kreatif juga cukup baik dan dapat dipahami oleh siswa, hal ini terlihat dari 26 orang siswa yang diberi tes berpikir kreatif semua siswa menjawab bahwa tes berpikir kreatif menggunakan bahasa yang baik. Ini artinya semua siswa dapat memahami apa yang diinginkan soal tersebut.

Namun, karena kurangnya kemampuan berpikir kreatif siswa dan kurang dalamnya pemahaman siswa terhadap materi pelajaran tersebuat sehingga siswa-siswi SMA Darussalam tidak dapat menyelesaikan tes berpikir kreatif dengan baik. Sehingga pada pertanyaan lainya yang ada di kuesioner, siswa-siswi SMA Darussalam memberikan jawaban yang tidak setuju. Dari paparan diatas maka dapat disimpulkan bahwa tes berpikir kreatif akuntansi yang telah dikembangkan sudah sesuai dengan materi dan karakteristik berpikir kreatif dan memenuhi kriteria keefektifan yang ditetapkan sehingga dapat dilanjutkan ke ujicoba lebih luas.

Tabel 15. Hasil Lembar Observasi Respon Siswa Terhadap Keterbacaan Tes Berpikir Kreatif.

\begin{tabular}{|c|c|c|c|c|c|}
\hline \multirow[t]{2}{*}{ No } & \multirow[t]{2}{*}{ Aspek yang diamati } & \multicolumn{2}{|c|}{ Respon } & \multicolumn{2}{|c|}{ Persentase } \\
\hline & & Agree & Disagree & Agree & Disagree \\
\hline \multirow[t]{5}{*}{ I } & Kepekasn pada Tes & & & & \\
\hline & $\begin{array}{l}\text { a. Apakah materi pembelajaran } \\
\text { sesuai dengan isi tes? }\end{array}$ & 26 & 0 & $100.00 \%$ & $00.00 \%$ \\
\hline & $\begin{array}{l}\text { b. Apakah anda memahami apa } \\
\text { yang ditanyakan pada ters? }\end{array}$ & 15 & 11 & $57.69 \%$ & $42.31 \%$ \\
\hline & $\begin{array}{l}\text { c. Apakah bahasa yang } \\
\text { disunakan pada tes baik? }\end{array}$ & 26 & 0 & $100.00 \%$ & $00.00 \%$ \\
\hline & $\begin{array}{l}\text { d. Apakah gambar yang } \\
\text { digunakan pada tes menarik? }\end{array}$ & 14 & 12 & $53.85 \%$ & $46.15 \%$ \\
\hline \multicolumn{2}{|r|}{ Rata -rata } & & & $77.89 \%$ & $22.12 \%$ \\
\hline \multirow[t]{4}{*}{ II } & Katagoxi Tes & & & & \\
\hline & $\begin{array}{l}\text { a. Apakah soal pada tes pada } \\
\text { gulit? }\end{array}$ & 20 & 6 & $76.92 \%$ & $23.08 \%$ \\
\hline & $\begin{array}{l}\text { b. Apakah soal pada tes pada } \\
\text { mudah? }\end{array}$ & 6 & 20 & $23.08 \%$ & $76.92 \%$ \\
\hline & $\begin{array}{l}\text { c. Apakah soal pada tes pada } \\
\text { sedang? }\end{array}$ & 5 & 21 & $19.23 \%$ & $80.77 \%$ \\
\hline \multicolumn{2}{|c|}{ Rata-rata } & & & $39.74 \%$ & $60.26 \%$ \\
\hline \multirow[t]{5}{*}{ III } & Tes bexpikix kreatif & & & & \\
\hline & $\begin{array}{l}\text { a. Apakah anda dapat meniaviab } \\
\text { tes dengan lancar? }\end{array}$ & 6 & 20 & $23.08 \%$ & $76.92 \%$ \\
\hline & $\begin{array}{l}\text { b. Apakah anda dapat meniawabb } \\
\text { tes dengan luwes banvalk } \\
\text { jawaban? }\end{array}$ & 6 & 20 & $23.08 \%$ & $76.92 \%$ \\
\hline & $\begin{array}{l}\text { c. Apakah anda dapat meniawabh } \\
\text { tes dengan asli/ iavaban yang } \\
\text { tidak biasa dikeriakan? }\end{array}$ & 8 & 18 & $30.77 \%$ & $69.23 \%$ \\
\hline & $\begin{array}{l}\text { d. Apakah anda dapat menjauvab } \\
\text { tes dengan rinci dengan } \\
\text { membuat gambar gerafik? }\end{array}$ & 10 & 16 & $38.46 \%$ & $61.54 \%$ \\
\hline \multicolumn{2}{|c|}{ Rata-rata } & & & $28.85 \%$ & $71,15 \%$ \\
\hline \multirow[t]{2}{*}{ IV } & Jaktu & & & & \\
\hline & $\begin{array}{l}\text { Apakah waktor yang digunakan } \\
\text { untuk menvelesaikan tes cukup? }\end{array}$ & 14 & 12 & $53.85 \%$ & $46.15 \%$ \\
\hline \multicolumn{2}{|c|}{ Rata-rata } & & & $53.85 \%$ & $46.15 \%$ \\
\hline
\end{tabular}

Sumber: Data diolah (2020)

Tahapan -4 Uji coba lebih luas

Setelah dilaksanakan uji coba terbatas, maka diperoleh bahwa tes berpikir kreatif akuntansi yang dikembangkan layak untuk diujicobakan secara lebih luas tanpa revisi. Uji coba lebih luas ini dilaksanakan di dua kelas yaitu kelas IPA 1 dan IPA 2.

A. Hasil Pengujian Keefektifan Tes Berpikir Kreatif pada Kelas IPA 1

Dari hasil uji coba pada kelas IPA 1 diperoleh rata-rata hasil tes berpikir kreatif akuntansi pada soal pertama sebesar 70.23. Dari hasil perhitungan rata-rata, maka dapat disimpulkan 
bahwa 35,71\% siswa dapat menyelesaikan soal pertama tes berpikir kreatif dengan baik dan benar. Pada soal ini siswa diminta untuk menjawab soal dengan tingkat berpikir kreatif dengan karakteristik fluency (lancar), pada soal ini hanya menghitung nilai dengan cara menambahkan, mengurangkan nilai dan membolak-balik angka saja.

Pada soal ke dua dengan karakteristik flexibility (luwes) diperoleh nilai rata-rata siswa sebesar 68.75. Hal ini artinya 28,57\% siswa dapat menjawab soal ini. Pada soal kedua ini, siswa diminta untuk menjawab pertanyaan dengan beberapa cara. Siswa dapat menjawab dengan satu cara, dua cara dan maksimal dengan tiga cara.

Pada soal ketiga tes berpikir kreatif dengan karakteristik orisinal (keaslian), jawaban yang benar dan harus berbeda dengan kebanyakan jawaban teman yang lain diperoleh nilai rata sebesar 45,54. Dari 28 siswa hanya 2 orang yang memiliki jawaban yang benar dan berbeda dengan yang lainnya. Dari hasil perhitungan rata-rata nilai siswa, maka dapat disimpulkan bahwa pada soal ke tiga hanya $3,57 \%$ siswa yang dapat menjawab soal tes berpikir kreatif akuntansi tersebut.

Soal tes berpikir kreatif pada nomor empat diperoleh nilai rata-rata sebesar 37.5. Pada soal nomor empat ini siswa diminta untuk menjawab tes berpikir kreatif dengan terperinci dari 28 siswa yang diberikan tes berpikir kreatif akuntansi tidak ada satupun siswa yang dapat menjawab soal secara terperinci. Beberapa siswa ada yang dapat menjawab tes berpikir kreatif dengan benar tapi tidak secara terperinci. Dapat disimpulkan bahwa pada soal tes berpikir kreatif akuntansi nomor empat dengan karakteristik elaboration (terperinci) tidak ada siswa yang memiliki karakteristik tersebut.

Dari paparan diatas dapat disimpulkan rata-rata kemampuan berpikir kreatif siswa IPA 1 di SMA Darussalam sebesar 55.28 yang artinya 16,96\% memiliki kemampuan berpikir kreatif akuntansi dan sisanya $83.31 \%$ siswa belum memiliki kemampuan berpikir kreatif.Hal ini berarti bahwa kemampuan berpikir kreatif siswa IPA 1 SMA Darussalam belum efektif dikarenakan $85 \%$ siswa tidak dapat memperoleh nilai minimum rata-rata sebesar 60. Maka, perlu perbaikan pada faktor pendukung lain yang tidak diteliti pada penelitian ini.

B. Hasil Pengujian Keefektifan Tes Berpikir Kreatif pada Kelas IPA 2

Uji coba lebih luas selanjutnya dilaksanakan dikelas IPA 2 sebanyak 26 orang siswa dan dari hasil uji coba diperoleh nilai rata-rata siswa tersebut pada soal nomor pertama sebesar 66,67. Hal ini menunjukkan bahwa siswa memiliki kemampuan berpikir kreatif dengan karakteristik fluency (lancar) dimana siswa yang dapat menjawab pertanyaan dengan lancar dan benar sebanyak 32\% dan selebihnya yaitu $68 \%$ siswa dapat menjawab dengan benar tetapi tidak lancar dan ada yang menjawab tetapi salah dan tidak lancar.

Pada soal nomor dua tes berpikir kreatif akuntansi, siswa dituntut dapat mengeluarkan ide-ide dan gagasannya untuk dapat menjawab soal tersebut, siswa dapat menjawab tes berpikir kreatif dengan beberapa cara dengan kata lain siswa memiliki karakteristik flexibility (luwes). Siswa yang memiliki karakteristik flexibility (luwes) sebanyak $20 \%$ atau rata-rata nilai 53.

Soal nomor tiga berpikir kreatif akuntansi memiliki karakteristikorisinal (keaslian) yaitu siswa dapat menjawab soal dengan cara yang tak biasa atau berbeda dengan jawab siswa lainnya, pada karakteristik ini tidak ada siswa yang dapat menjawab dengan benar dan jawabannya berbeda dengan jawaban siswa lainnya. Rata-rata nilai siswa pada soal ini sebesar 39,00. Maka, dapat disimpulkan bahwa tidak terdapat siswa yang memiliki kemampuan berpikir kreatif pada karateristik orisinal, dikarenakan siswa menjawab benar tapi proses jawaban sama dengan teman lainnya da nada juga siswa menjawab salah dan proses jawaban sama dengan jawaban teman lainnya. 
Pada karakteristik ke empat yaitu elaboration (terperinci) yaitu menjawab soal tes berpikir kreatif dengan benar dan secara terperinci. Namun, kebanyakan siswa menjawab dengan jawaban benar tapi tidak terperinci dimana rata-rata nilai siswa dalam menjawab tes berpikir kreatif ini sebesar 28 dengan 0\% siswa yang memiliki kemapuan elaboration (terperinci).

Dari paparan diatas dapat dijelaskanbahwa nilai rata-rata siswa yang memiliki kemampuan berpikir kreatif sebesar 46.67 dengan persentase sebesar 13\%. Dapat disimpulkan bahwa tes berpikir kreatif tidak efektif dikarenakan $85 \%$ siswa tidak memiliki nilai minimum rata-rata sebesar 60. Maka, perlu peninjauan ulang faktor lainnya terhadap proses pembelajaran siswa yang tidak diteliti pada penelitian ini.

C. Keberagaman Bentuk Proses Jawaban Siswa dalam Menyelesaikan Tes Berpikir Kreatif Akuntansi

Berdasarkan hasil uji coba lebih luas diperoleh pola jawaban siswa untuk setiap butir soal tes berpikir kreatif akuntansi yang dikategorikan dalam aspek lancar, luwes, asli dan terperinci.

Proses Jawaban Butir Soal Tes Berpikir Kreatif Akuntansi pada Soal Nomor 1.

Pada soal nomor satu siswa dituntut untuk menjawab soal tes berpikir kreatif akuntansi dengan lancar yang artinya jawaban harus benar dan proses jawaban juga harus benar.

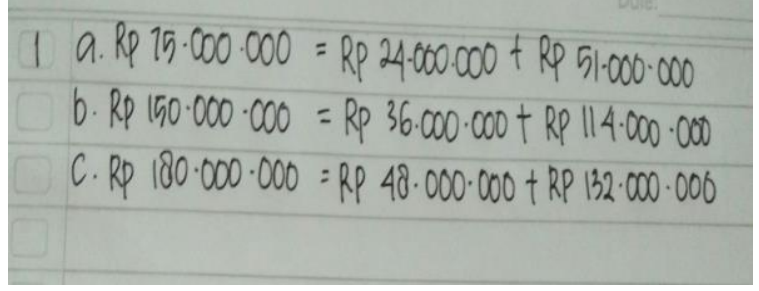

Gambar 2. Bentuk penyelesaian soal berpikir kreatif akuntansi nomor 1

Sumber: Data diolah (2020)

Dari gambaran jawaban siswa di atas, siswa dapat menyelesaikan tes dengan benar dimana hampir seluruh siswa menjawab tes berpikir kreatif pada soal nomor satu tersebut seperti jawaban pada gambaran di atas. Meskipun, ada beberapa siswa yang menjawab tapi jawabannya tidak benar walaupun proses jawabannya sudah benar. Dan beberapa siswa menjawab benar tetapi tidak lengkap dalam menjawab tes berpikir kreatif di atas, terlihat siswa dapat menyelesaikan soal dengan memilih dari beberapa informasi yang telah diberikan pada soal dan menyelesaikannnya secara benar. Aspek berpikir kreatif pada soal nomor satu dengan katagori luwes atau lancar sudah dimiliki oleh siswa SMA Darussalam

Proses Jawaban Butir Soal Tes Berpikir Kreatif Akuntansi pada Soal Nomor 2.

Soal nomor dua pada tes berpikir kreatif siswa dituntut untuk menjawab dengan benar dengan menggunakan proses jawaban yang sesuai dengan hasil dan dapat menyelesaikannnya dengan beberapa cara,namun pada tes berpikir kreatif yang dikembangkan ini hanya memiliki dua cara yang berbeda saja. 


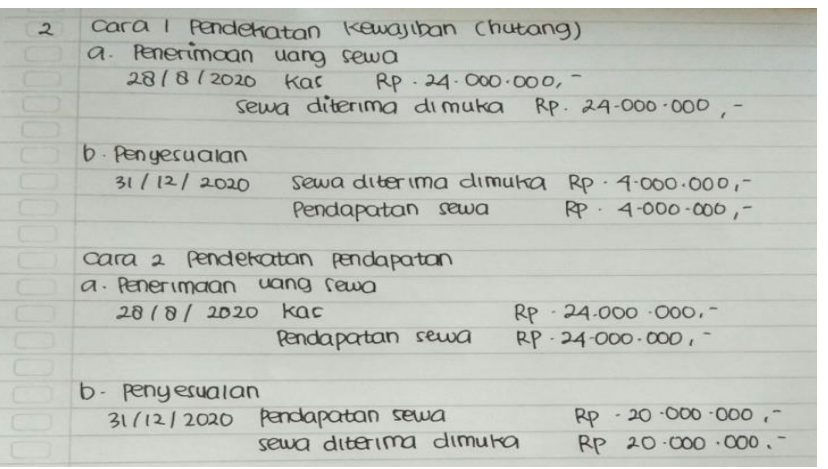

Gambar 3. Bentuk penyelesaian soal berpikir kreatif akuntansi nomor 2 Sumber: Data diolah (2020)

Pada proses jawaban diatas telah sesuai dengan karakteristik berpikir kreatif dengan kategori flexibility (luwes). Siswa dapat menjawab soal dengan benar dan menyelesaikannya dengan menggunakan dua cara yang berbeda. Namun, masih ada beberapa siswa yang tidak dapat menyelesaikan tes tersebut secara benar tetapi proses penyesaiannya sudah benar. Selain itu ada beberapa siswa dapat menyelesaikan soal dengan benar tetapi proses penyelesaiannya yang tidak sesuai. Lainnya, ada juga yang menjawab dengan benar tetapi hanya menggunakan satu proses jawaban saja. Dan beberapa siswa tidak dapat menjawab dengan benar dan proses jawaban juga tidak sesuai.

Proses Jawaban Butir Soal Tes Berpikir Kreatif Akuntansi pada Soal Nomor 3.

Pada soal berpikir kreatif nomor tiga, siswa dituntut dapat menjawab soal secara benar dan proses jawaban siswa harus berbeda dengan jawaban siswa lainnya.

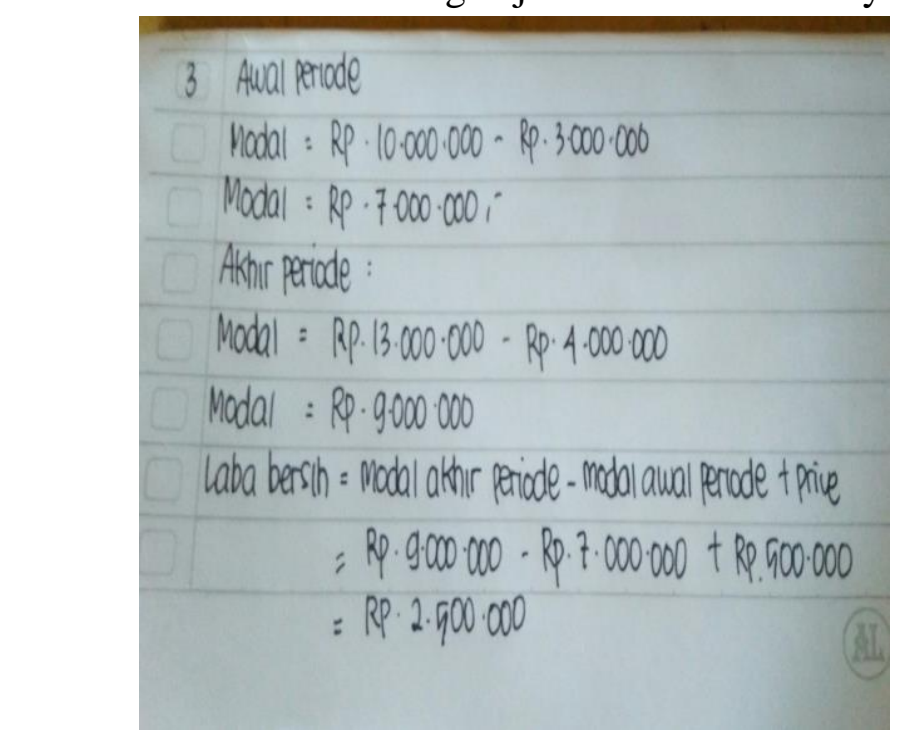

Gambar 4. Bentuk penyelesaian soal berpikir kreatif akuntansi nomor 3 Sumber: Data diolah (2020)

Gambaran proses jawaban siswa pada soal nomor tiga diatas sudah benar namun, beberapa siswa dalam menjawab tes tersebut proses mendapatkan hasilnya sama. Jadi, tidak ada proses jawaban siswa yang berbeda dari teman lainnya, maka dapat disimpulkan bahwa pada kategori orisinal (keaslian) ini belum dimiliki oleh siswa SMA Darussalam. Beberapa siswa menjawab benar, namun proses jawaban salah dan beberapa siswa lainnyacara menjawab salah dan hasil jawabannya juga salah.

Proses Jawaban Butir Soal Tes Berpikir Kreatif Akuntansi pada Soal Nomor 4.

Pada soal nomor empat ini, siswa dituntut dapat menjawab soal tes berpikir kreatif akuntasi dengan benar dan proses jawaban harus dijawab secara terperinci. 
Pada gambar 5, proses jawaban siswa pada soal nomor empat tidak sesuai dengan jawaban yang sebenarnya diperoleh siswa dan proses jawaban tersebut belum dikatakan terperinci. Kebanyakan siswa tidak menjawab seperti yang terlihat pada gambar. Beberapa siswa tidak dapat menyelesaikanproses jawaban dan hasil jawaban juga salah dan beberapa siswa mencobamenjawabtetapi jawaban tidak benar dan proses jawaban juga tidak terselesaikan. Bahkan beberapa siswa tidak menjawab sama sekali bahkan hanya menuliskan nomor soal saja tanpa ada proses jawaban maupun jawabannya. Maka, dapat disimpulkan bahwa pada soal tes berpikir kreatif akuntansi untuk nomor empat, siswa belum dapat menyelesaikan soal secara benar dan terperinci.Siswa belum memiliki kemampuan berpikir kreatif pada kategori elaboration (terperinci).

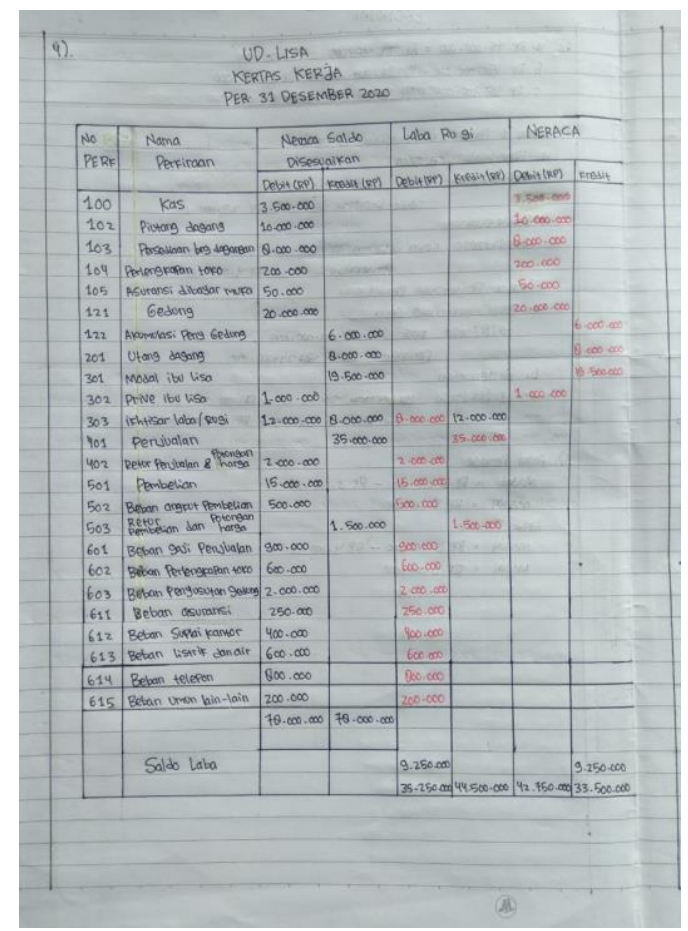

Gambar 5. Bentuk penyelesaian soal berpikir kreatif akuntansi nomor 4 Sumber: Data diolah (2020)

\section{Sensitivitas Tes Berpikir Kreatif Kelas IPA 1}

Sensitivitas tes berpikir kreatif akan diperoleh apabila unsur kevalidan, tingkat kesukaran, daya pembeda dan reliabilitas tes berpikir kreatif diperoleh maka, untuk yang pertama kualitas tes dikatakan baikapabila tes tersebut valid. Pada tabel di bawah ini akan diuraikan hasil perhitungan validitas, tingkat kesukaran, daya pembeda dan reliabilitas dari soal tes.

Validitas tes berpikir kreatif akuntansi.

Tabel 16. Hasil Uji Validitas Tes Berpikir Kreatif Akuntansi

\begin{tabular}{ccccc}
\hline $\begin{array}{c}\text { Nomor } \\
\text { Soal }\end{array}$ & $\begin{array}{c}\text { Nilai } \\
r_{x y}\end{array}$ & Kriteria & $r_{\text {tabel }}$ & Keterangan \\
\hline 1 & 0,949 & Tinggi & 0,388 & Valid \\
2 & 0,963 & Tinggi & 0,388 & Valid \\
3 & 0,982 & Tinggi & 0,388 & Valid \\
4 & 0,964 & Tinngi & 0,388 & Valid \\
\hline
\end{tabular}

Sumber: Data diolah (2020) 
Berdasarkan hasil perhitungan validitas tes yang tertera pada tabel diatas diperoleh tes berpikir kreatif yang dikembangkan adalah valid dengan kriteria tingkat kevalidan tinggi.

Tingkat kesukaran tes berpikir kreatif akuntansi.

Setelah dilakukan perhitungan validitas tes maka, langkah selanjutnya untuk melihat apakah tes tersebut berkualitas dengan menghitung tingkat kesukaran tes. Berikutakan disajikan tingkat kesukaran tes berpikir kreatif akuntansi yang dikembangkan.

Tabel 17. Tingkat Kesukaran Tes Berpikir Kreatif

\begin{tabular}{ccccc}
\hline $\begin{array}{c}\text { Aspek yang } \\
\text { dinilai }\end{array}$ & Butir 1 & Butir 2 & Butir 3 & Butir 4 \\
\hline $\begin{array}{c}\text { Indeks } \\
\text { Interpretasi }\end{array}$ & 0.702 & 0.688 & 0.446 & 0.375 \\
Mudah & Sedang & Sedang & Sedang \\
\hline \multicolumn{5}{c}{ Sumber: Data diolah (2020) }
\end{tabular}

Dari hasil perhitungan butir soal tes berpikir kreatif akuntansi diperoleh tingkat kesukaran pada nomor satu sebesar 0.702 dengan kriteria mudah artinya soal nomor satu dapat diselesaikan dengan mudah. Selanjutnya butir soal pada nomor 2, 3 dan 4 beturut-turut sebesar $0.688,0446$ dan 0.375 dengan kriteria sedang. Soal tersebut dalam kategori tidak mudah dan tidak juga sulit atau dalam tingkat kesulitan menengah.

Daya pembeda tes berpikir kreatif akuntansi.

Selanjutnya dipaparkan perhitungan daya pembeda soal pada tabel di bawah ini.

Tabel 18. Daya Pembeda Soal Tes Berpikir Kreatif Akuntansi

\begin{tabular}{lcccc}
\hline Aspek yang Dinilai & Soal 1 & Soal 2 & Soal 3 & Soal 4 \\
\hline $\begin{array}{l}\text { Skor Maks Ideal } \\
\text { Rata-rata Skor }\end{array}$ & 3 & 4 & 4 & 4 \\
Kelompok Atas & 2.714 & 3.571 & 2.786 & 2.786 \\
Rata-rata Skor & & & & \\
Kelompok Bawah & 1.500 & 1.929 & 0.786 & 0.214 \\
Indeks & 0.405 & 0.411 & 0.500 & 0.643 \\
Interpretasi & Baik & Baik & $\begin{array}{c}\text { Sangat } \\
\text { Baik }\end{array}$ & $\begin{array}{c}\text { Sangat } \\
\text { Baik }\end{array}$ \\
\hline
\end{tabular}

Sumber: Data diolah (2020)

Dari data tabel di atas, diperoleh daya pembeda soal pada nomor satu dan dua memiliki nilai sebesar 0.405 dan 0.411 dengan kriteria baik. Maka, soal nomor satu dan dua dapat mengukur siswa yang memiliki kemampuan berpikir kreatif tinggi dengan siswa yang memiliki kemampuan rendah dalam tes berpikir kreatif. Pada soal nomor tiga dan empat memiliki nilai sebesar 0.500 dan 0.643 dengan kriteria sangat baik. Artinya pada soal nomor tiga dan empat sangat baik dalam membedakan siswa yang memiliki kemauan berpikir kreatif.

Reliabilitas tes berpikir kreatif akuntansi

Perhitungan selanjunya adalah dengan menghitung reliabilitas tes berpikir kreatif akuntansi yang akan disajikan pada tabel berikut ini.

Tabel 19. Reliabilitas Tes Berpikir Akuntansi

\begin{tabular}{cr}
\hline Cronbach's Alpha & N of Items \\
\hline Sumber: Data diolah (2020)
\end{tabular}


Hasil perhitungan koefisien reliabilitas kemudian ditafsirkan dan diinterpretasikan dan diperoleh nilai reliabitas sebesar 0.962 dengan kriteria sangat tinggi, maka dapat disimpulkan bahwa tes berpikir kreatif yang dikembangkan memiliki kualitas tes yang cukup baik.

Sensitivitas tes berpikir kreatif akuntansi.

Tes berpikir kreatif akuntansi yang telah didesain oleh peneliti kemudian divalidasi oleh ahli akuntansi dan dikembangkan melalui uji coba terbatas pada kelas IPS dan diperoleh hasil nilai sensitivitas pada soal nomor satu dan empat memiliki kepekaan dan soal nomor dua dan nomor tiga tidak memiliki kepekaaan. Selanjutnya tes berpikir kreatif akuntansi yang dikembangkan diujicobakan pada kelas IPA 1. Sensitivitas tes berpikir kreatif akuntansi pada ujicoba lebih luas diperoleh:

Tabel 20. Sensitivitas Tes Berpikir Kreatif pada Uji Coba Luas

\begin{tabular}{ccccc}
\hline $\begin{array}{c}\text { Aspek } \\
\text { yang } \\
\text { dinilai }\end{array}$ & Butir 1 & Butir 2 & Butir 3 & Butir 4 \\
\hline Indeks & 0.607 & 0.678 & 0.500 & 0.464 \\
Interpretasi & Peka & Peka & Peka & Peka \\
\hline \multicolumn{5}{c}{ Sumber: Data diolah (2020) }
\end{tabular}

Dari tabel diatas terlihat hasil perhitungan keempat butir soal tes berpikir kreatif akuntansi yang diujicobakan pada kelas IPA 1 diperoleh nilai sensitivitas berturut-turut sebesar $0.607,0.678,0.500$, dan 0.464 . Hasil ini lebih besar dari $\mathrm{S} \geq 0,30$ sehingga dapat disimpulkan bahwa kriteria keempat butir soal tes berpikir kreatif akuntansi peka terhadap pembelajaran akuntansi yang telah dipelajari oleh siswa kelas IPA 1 SMA Darussalam.

E. Sensitivitas Tes Berpikir Kreatif IPA 2

Uji coba lebih luas selanjutnya dilaksanakan di kelas IPA 2. Pada uji coba luas ini dilaksanakan untuk melihat tes berpikir kreatif yang dikembangkan memiliki kualitas tes yang baik. Untuk mengukur tes berpikir kreatif yang dikembangkan berkualitas maka, harus diperolah hasil perhitungan validitas, daya beda, tingkat kesukaran, reliabilitas dan sensitivitas tes. Sebelum peneliti memaparkan hasil perhitungan sensitivitas, maka dianalisis terlebih dahulu vadilitas tes yang akan disajikan pada tabel berikut ini.

Validitas tes berpikir kreatif akuntansi.

Setelah dilaksanakan uji coba lebih luas pada kelas IPA 1, selanjunya diujicobakan pada kelas IPA2. Setelah pelaksanaan uji coba dilaksanakan maka, diperoleh hasil jawaban tes berpikir kreatif akuntansi yang pertama dianalisis adalah validitas tes berpikir kreatif akuntansi yang akan disajikan pada tabel di bawah ini.

Tabel 21. Hasil Uji Validitas Tes Berpikir Kreatif Akuntansi

\begin{tabular}{ccccc}
\hline $\begin{array}{c}\text { Nomor } \\
\text { Soal }\end{array}$ & $\begin{array}{c}\text { Nilai } \\
r_{x y}\end{array}$ & Kriteria & $r_{\text {tabel }}$ & Keterangan \\
\hline 1 & 0,957 & Tinggi & 0,432 & Valid \\
2 & 0,972 & Tinggi & 0,432 & Valid \\
3 & 0,961 & Tinggi & 0,432 & Valid \\
4 & 0,972 & Tinngi & 0,432 & Valid \\
\hline \multicolumn{5}{c}{ Sumber: Data diolah $(2020)$} \\
\end{tabular}


Dari uraian tabel di atas, diperoleh hasil perhitungan validitas tes berpikir kreatif pada keempat soal adalah berturut-turut sebesar 0.957, 0.972, 0.961 dan 0.972 dengan analisis validitas dengan kriteria tingkat kevalidan sangat tinggi.

Tingkat kesukaran tes berpikir kreatif akuntansi.

Kriteria kedua suatu soal dikatakan berkualitas harus memiliki tingkat kesukaran. Perhitungan tingkat kesukaran soal tes berpikir kreatif akan disajikan pada tabel berikut ini.

Tabel 22. Tingkat Kesukaran Tes Berpikir Kreatif Akuntansi

\begin{tabular}{ccccc}
\hline $\begin{array}{c}\text { Aspek yang } \\
\text { dinilai }\end{array}$ & Butir 1 & Butir 2 & Butir 3 & Butir 4 \\
\hline Indeks & 0.667 & 0.530 & 0.390 & 0.280 \\
Interpretasi & Mudah & Sedang & Sedang & Sukar \\
\hline \multicolumn{5}{c}{ Sumber: Data diolah (2020) }
\end{tabular}

Berdasarkan tabel diatas, diperoleh nilai tingkat kesukaran pada soal nomor satu sebesar 0.667 dengan kriteria mudah. Soal nomor satu dapat diselesaikan siswa yang memiliki kemampuan berpikir kreatif maupun siswa yang belum memiliki kemampuan berpikir kreatif. Pada soal nomor dua dan nomor tiga diperoleh nilai tingkat kesukarannya sebesar 0.530 dan 0.390 dengan kriteria sedang yang artinya siswa yang dapat menyelesaikan soal nomor dua dan tiga yaitu siswa yang memiliki kemampuan berpikir kreatif dalam kategori sedang dan tinggi. Soal nomor empat diperoleh tingkat kesukarannya sebesar 0.280 dengan kriteria sukar, artinya siswa yang dapat menyelesaikan soal ini hanya siswa yang memiki kemampuan berpikir kreatif tinggi saja.

Daya pembeda tes berpikir kreatif akuntansi.

Daya pembeda soal berfungsi sebagai pembeda siswa yang dapat menyesaikan soal tes berpikir kreatif akuntansi dengan siswa yang tidak dapat menyelesaikan tes berpikir kreatif akuntansi. Daya pembeda soal yang diujicobakan pada kelas IPA 2 akan disajikan pada tabel 23..

Daya pembeda soal pada nomor satu, tiga dan empat diperoleh nilai berturut-turut sebesar 0.427, 0.492 dan 0.423 dengan kriteria baik. Artinya pada soal nomor satu, tiga dan empat dapat mengukur kemampuan berpikir kreatif siswa dengan baik. Soal tes berpikir kreatif pada soal nomor dua diperoleh hasil perhitungan daya pembeda soal sebesar 0.503 dengan kriteria sangat baik. Artinya pada soal nomor dua inidapat mengukur kemampuan berpikir kreatif dengan tingkat sangat baik.

Tabel 23. Daya Pembeda Soal Tes Berpikir Kreatif Akuntansi

\begin{tabular}{lcccc}
\hline Aspek yang Dinilai & Soal 1 & Soal 2 & Soal 3 & Soal 4 \\
\hline Skor Maks Ideal & 3 & 4 & 4 & 4 \\
Rata-rata Skor & & & & \\
Kelompok Atas & 2.667 & 3.167 & 2.583 & 2.000 \\
Rata-rata Skor & & & & \\
Kelompok Bawah & 1.385 & 1.154 & 0.615 & 0.308 \\
Indeks & 0.427 & 0.503 & 0.492 & 0.423 \\
Interpretasi & Baik & Sangat & Baik & Baik \\
& & Baik & & \\
& & &
\end{tabular}

Sumber: Data diolah (2020) 


\section{Reliabilitas tes berpikir kreatif akuntansi.}

Perhitungan reliabilitas tes berfungsi untuk melihat tes berpikir kreatif yang dikembangkan dapat dipercaya tanpa ada masalah kekeliruan dalam mendesain tes berpikir kreatif.

Tabel 24. Reliabilitas Tes Berpikir Akuntansi

\begin{tabular}{rr}
\hline Cronbach's Alpha & N of Items \\
\hline, 970 &
\end{tabular}

Dari perhitungan reliabitas dengan menggunakan SPSS versi 23 diperoleh hasil sebesar 0.970 dengan kriteria sangat tinggi. Maka dapat disimpulakan bahwa tes berpikir kreatif yang dikembangkan memiliki kualitas tes yang baik dan dapat dipergunakan pada sampel lainnya untuk megukur kemampuan berpikir kreatif siswa khususnya pelajaran akuntansi.

\section{Sensitivitas tes berpikir kreatif akuntansi}

Uji coba lebih luas selanjutnya dilaksanakan di kelas IPA 2. Pada uji coba luas ini dilaksanakan untuk melihat tes berpikir kreatif yang dikembangkan memiliki kepekaan terhadap pembelajaran akuntansi atau sebaliknya. Kategori tes berpikir kreatif akuntansi yang dikembangkan memiliki kepekaan apabila $S \geq 0,30$. Dari hasil perhitungan analisis data pada kelas ini diperoleh nilai sensivitas tes berpikir kreatif akuntansi yang tersaji pada tabel berikut ini.

Tabel 25. Sensitivitas Tes Berpikir Kreatif pada Uji Coba Luas

\begin{tabular}{ccccc}
\hline $\begin{array}{c}\text { Aspek } \\
\text { yang } \\
\text { dinilai }\end{array}$ & Butir 1 & Butir 2 & Butir 3 & Butir 4 \\
\hline Indeks & 0.360 & 0.423 & 0.160 & 0.280 \\
Interpretasi & Peka & Peka & Tidak & Tidak \\
& & & Peka & Peka \\
\hline
\end{tabular}

Sumber: Data diolah (2020)

Dari data yang disajikan pada tabel diatas diperoleh nilai sensitivitas tes berpikir kreatif akuntansi pada soal nomor satu dan soal nomor dua memiliki nilai sensitivitas sebesar 0.360 dan 0.423 yang artinya nilai tersebut lebih besar dari 0,30 sesuai dengan rumus $S \geq 0,30$. Maka dapat disimpulkan bahwa pada soal tes berpikir kreatif pada nomor satu dan nomor dua termasuk kedalam kategori peka (sensitif) terhadap hasil belajar akuntansi. Selanjunya nilai sensitivitas soal tes berpikir kreatif akuntansi pada nomor tiga dan nomor empat diperoleh nilai sensitivitas sebesar 0.160 dan 0,280, nilai sensivitas tersebut lebih kecil dari 0,30 yang artinya tes berpikir kreatif pada soal nomor tiga dan empat tidak memiliki kepekaan terhadap hasil belajar akuntansi. Hal ini dikarenakan pada soal nomor tiga dan empat pada tes berpikir kreatif yang dikembangkan memerlukan pemikiran yang cukup dalam untuk dapat menyelesaikannya sehingga pada soal nomor tiga dan empat ini siswa-siswi pada kelas IPA 2 perlu pembelajaran yang lebih mendalam lagi untuk menyelesaikan soal tersebut.

Dari paparan diatas maka, dapat disimpulkan bahwa berdasarkan hasil uji coba luas pada kelas IPA 1 dan IPA 2 diperoleh sensitivitas yang berbeda-beda pada setiap kelas. Dari hasil analisis peneliti diperoleh jawaban penyelesaian tes berpikir kreatif yang dikembangkan kurang memuaskan disebabkan karena jawaban siswa belum menunjukkan siswa dapat berpikir kreatif khususnya pada karakteristik orisinil dan terperinci. Hal ini disebabkan setiap siswa-siswi SMA Darussalam berbeda-beda kemampuannnya, khususnya pada kemampuan berpikir kreatif akuntansi. 
F.Respon siswa terhadap tes berpikir kreatif akuntansi pada kelas IPA 1

Setelah dilaksanakan uji coba lebih luas terhadap siswa di kelas IPAv1 SMA Darussalam, selanjunya peneliti memberikan angket untuk melihat respon siswa terhadap tes berpikir kreatif akuntansi yang telah dikembangkan. Analisis data respon siswa akan disajikan pada tabel 26.

Dari tabel diperoleh respon siswa terhadap tes berpikir kreatif akuntansi yang dikembangkan memiliki kepekaan pada tes sebesar $86.61 \%$ dengan kategori sangat positif, maka dapat disimpulkan bahwa kepekaan tes berpikir kreatif akuntansi efektif terhadap siswa. Respon siswa pada kategori tes diperoleh hasil perhitungan dengan rata-rata sebesar $51.19 \%$ dengan kategori cukup namun, belum efektif dikarenakan respon siswa belum mencapai $80 \%$. Hal ini disebabkan respon siswa lebih banyak menyatakan tes berpikir kreatif yang dikembanngkan memiliki tingkat yang cukup sulit. Dalam menyelesaikan tes tersebut diperlukan pembelajaran yang lebih lama dan mendalam lagi. Selanjutnya pada kategori tes berpikir kreatif, siswa memberi respon sebesar $64.68 \%$ dengan kriteria positif, namun belum efektif. Dari hasil analisis peneliti terhadap respon siswa, tes berpikir kreatif yang dikembangkan memerlukan jawaban yang memiliki jalan penyesaiannya yang bermacam-macam, harus berbeda dengan jawaban teman lainnnya dan harus terperinci dengan membuat tabel yang lengkap. Dalam proses menyelesaikan jawaban tes tersebut, siswa tidak menemukan ide-ide dan gagasan seperti paparan diatas sehingga respon siswa terhadap tes berpikir kreatif kurang efektif. Adapun respon siswa terhadap waktu dalam menyelesaikan tes tersebut sebesar $75 \%$ dengan kriteria positif dan belum efektif. Hal ini dikarenakan pada masa pandemi Covid 19 ini, pembelajaran dilakukan secara daring (online) menyebabkan beberapa siswa tidak dapat menyelesaikannya sesuai dengan petunjuk tes. Kebanyakan siswa memerlukan waktu yang lama dalam menyelesaikannya, hal ini terlihat dari sebagian siswa tidak langsung mengirimkan jawabannya.

Tabel 26. Hasil Lembar Observasi Respon Siswa Terhadap Keterbacaan Tes Berpikir Kreatif

\begin{tabular}{|c|c|c|c|c|c|}
\hline \multirow[t]{2}{*}{ No } & \multirow[t]{2}{*}{ Aspek yang diamati } & \multicolumn{2}{|c|}{ Respon } & \multicolumn{2}{|c|}{ Persentase } \\
\hline & & Agree & Disagree & Agree & Disagree \\
\hline \multirow[t]{5}{*}{ I } & Kepeksan pada Tes & & & & \\
\hline & $\begin{array}{l}\text { a. Apakah materi pembelajaran } \\
\text { gevuai densan isi ter? }\end{array}$ & 28 & 0 & $100.00 \%$ & $00.00 \%$ \\
\hline & $\begin{array}{l}\text { b. Apakah anda memahami ana } \\
\text { yang ditanyakan pada tes? }\end{array}$ & 21 & 6 & $75.00 \%$ & $25.00 \%$ \\
\hline & $\begin{array}{l}\text { c. Apakah bahasa yang } \\
\text { digunalkan pada tes baik? }\end{array}$ & 28 & 0 & $100.00 \%$ & $00.00 \%$ \\
\hline & $\begin{array}{l}\text { d. Apakah gambar yang } \\
\text { digunakan pada tes menarik? }\end{array}$ & 20 & 8 & $71.43 \%$ & $28.57 \%$ \\
\hline \multicolumn{2}{|c|}{ Rata -rata } & & & $86.61 \%$ & $13.39 \%$ \\
\hline \multirow[t]{4}{*}{ II } & Kategori Tes & & & & \\
\hline & $\begin{array}{l}\text { a. Apakah soal pada tes pada } \\
\text { sulit? }\end{array}$ & 18 & 10 & $64.29 \%$ & $35.71 \%$ \\
\hline & $\begin{array}{l}\text { b. Apakah soal pada tes pada } \\
\text { mudah? }\end{array}$ & 11 & 17 & $39.29 . \%$ & $60.71 \%$ \\
\hline & $\begin{array}{l}\text { c. Apakah soal pada tes pada } \\
\text { gedang? }\end{array}$ & 14 & 14 & $50.00 \%$ & $50.00 \%$ \\
\hline \multicolumn{2}{|c|}{ Rata-rata } & & & $51.19 \%$ & $48.87 \%$ \\
\hline \multirow[t]{5}{*}{ III } & Tes Berpikix Kneatif & & & & \\
\hline & $\begin{array}{l}\text { a. Apakah anda dapat meniawaba } \\
\text { tem dengan lancar? }\end{array}$ & 20 & 8 & $71.43 \%$ & $28.57 \%$ \\
\hline & $\begin{array}{l}\text { b. Apakah anda dapat menianval } \\
\text { teg dengan luwes' banvalk } \\
\text { jawaban? }\end{array}$ & 16 & 12 & $57.14 \%$ & $42.86 \%$ \\
\hline & $\begin{array}{l}\text { c. Apakah anda dapat menjanvalo } \\
\text { tes dengan aslij iawaban yang } \\
\text { tidak bjazsa dikeriakan? }\end{array}$ & 18 & 10 & $64.29 \%$ & $35.71 \%$ \\
\hline & $\begin{array}{l}\text { d. Apakah anda dapat meniawuala } \\
\text { tes dengan rinci/ dengan } \\
\text { membuat gambar, gerafik? }\end{array}$ & 19 & 9 & $67.86 \%$ & $32.14 \%$ \\
\hline \multicolumn{2}{|r|}{ 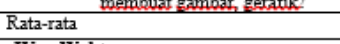 } & & & $64.68 \%$ & $34.82 \%$ \\
\hline \multicolumn{2}{|c|}{ IV JTaktu } & & & & \\
\hline \multicolumn{2}{|c|}{$\begin{array}{l}\text { Apakah wakto yang digunakan } \\
\text { untuk menxelesaikan tes sulap?? }\end{array}$} & 21 & 7 & $53.85 \%$ & $46.15 \%$ \\
\hline \multicolumn{2}{|r|}{ Rata-rata } & & & $75.00 \%$ & $25.00 \%$ \\
\hline
\end{tabular}

Sumber: Data diolah (2020)

G. Respon siswa terhadap tes berpikir kreatif akuntansi pada kelas IPA 2 
Uji coba selanjutnya dilaksanakan dikelas IPA 2. Respon siswa kelas IPA 2 terhadap tes berpikir kreatif yang dikembangkan dapat dilihat pada tabel dibawah ini.

Tabel 27. Hasil Lembar Observasi Respon Siswa Terhadap Keterbacaan Tes Berpikir Kreatif.

\begin{tabular}{|c|c|c|c|c|c|}
\hline \multirow[t]{2}{*}{ No } & \multirow[t]{2}{*}{ Aspek yang diamati } & \multicolumn{2}{|c|}{ Respon } & \multicolumn{2}{|c|}{ Persentase } \\
\hline & & Agree & Disagree & Agree & Disagree \\
\hline \multirow[t]{5}{*}{ I } & Kepekasn pada Tes & & & & \\
\hline & $\begin{array}{l}\text { a. Apakah materi pembelajaran } \\
\text { gefuai dengan isi tes? }\end{array}$ & 25 & 0 & $100.00 \%$ & $00.00 \%$ \\
\hline & $\begin{array}{l}\text { b. Apakah anda memahami apa } \\
\text { yang ditanyakan pada tes? }\end{array}$ & 21 & 4 & $84.00 \%$ & $16.00 \%$ \\
\hline & $\begin{array}{l}\text { c. Apakah bahasa yang } \\
\text { digunakan pada tes baik? }\end{array}$ & 25 & 0 & $100.00 \%$ & $00.00 \%$ \\
\hline & $\begin{array}{l}\text { d. Apakah gambar yang } \\
\text { digunakan pada tas menarik? }\end{array}$ & 21 & 4 & $84.00 \%$ & $16.00 \%$ \\
\hline \multicolumn{2}{|c|}{ Rata-rata } & & & $92.00 \%$ & $08.00 \%$ \\
\hline \multirow[t]{4}{*}{ II } & Katagori Tes & & & & \\
\hline & $\begin{array}{l}\text { a. Apakah soal pada tes pada } \\
\text { sulit? }\end{array}$ & 15 & 10 & $60.00 \%$ & $40.00 \%$ \\
\hline & $\begin{array}{l}\text { b. Apakah soal pada tes pada } \\
\text { mudah? }\end{array}$ & 11 & 14 & $44.00 \%$ & $56.00 \%$ \\
\hline & $\begin{array}{l}\text { c. Apakah soal pada tes pada } \\
\text { gedang? }\end{array}$ & 11 & 14 & $44.00 \%$ & $56.00 \%$ \\
\hline \multicolumn{2}{|c|}{ Rata-rata } & & & $49.33 \%$ & $50.67 \%$ \\
\hline \multicolumn{6}{|c|}{ III Tes bexpikix kxeatif } \\
\hline & $\begin{array}{l}\text { a. Apakah anda dapat menjaxiab } \\
\text { ten dengan lancar? }\end{array}$ & 22 & 3 & $88.00 \%$ & $12.00 \%$ \\
\hline & $\begin{array}{l}\text { b. Apakah anda dapat menjaxxab } \\
\text { tes dengan luwes banvalk } \\
\text { jayaban? }\end{array}$ & 20 & 6 & $80.00 \%$ & $20.00 \%$ \\
\hline & $\begin{array}{l}\text { c. Apakah anda dapat menjaxiab } \\
\text { tes dengan asli/ iawaban yang } \\
\text { tidak biasa diketiakan? }\end{array}$ & 15 & 10 & $60.00 \%$ & $40.00 \%$ \\
\hline & $\begin{array}{l}\text { d. Apakah anda dapat menjaxiab } \\
\text { tes dengan rincil dengan } \\
\text { membuat gambar gerafik? }\end{array}$ & 19 & 6 & $76.00 \%$ & $24.00 \%$ \\
\hline \multicolumn{2}{|c|}{ Rata-rata } & & & $76.00 \%$ & $24.00 \%$ \\
\hline \multicolumn{2}{|c|}{ IV Jakty } & & & & \\
\hline \multicolumn{2}{|c|}{$\begin{array}{l}\text { Apakah wraktu yang digmaakan } \\
\text { unutuk menvelesaikan tes culkup? }\end{array}$} & 20 & 5 & $53.85 \%$ & $46.15 \%$ \\
\hline \multicolumn{2}{|c|}{ Rata-rata } & & & $80.00 \%$ & $20.00 \%$ \\
\hline
\end{tabular}

Sumber: Data diolah (2020)

Pada tabel diatas dapat peneliti analisis respon siswa terhadap kepekaan tes berpikir kratif yang dikembangkan mendapat respon sebesar 92\% dengan kriteria positif yang artinya tes memiliki kepekaan terhadap siswa. Selanjunya kategori tes berpikir kreatif yang dikembangkan mendapat respon sebesar $49.33 \%$ dengan kriteria cukup yang artinya soal tersebut kurang efektif terhadap siswa karena persentase siswa tidak sampai 80\%. Hal ini dapatdisimpulkan dari respon siswa yang didapat bahwa tes berpikir kreatif yang dikembangkan cukup sulit untuk diselesaikan siswa. Tes berpikir kreatif akuntansi mendapat respon dari siswa sebesar $76 \%$ dengan kriteria positif, namun belum efektif bagi siswa dikarenakan respon siswa belum mencapai $80 \%$. Hal ini dapat disimpulkan bahwa tes berpikir kreatif yang dikembangkan memerlukan pemikiran dan proses pembelajaran yang cukup mendalam dalam menyelesaikannya. Respon siswa terhadap waktu penyelesaian tes berpikir kreatif yang dikembangkan memperoleh hasil sebesar $80 \%$ dengan kategori sangat positif dan efektif terhadap waktu yang diperlukan siswa dalam menyelesaikan tes tersebut.

Dari paparan-paparan di atas dapat disimpulkan bahwa kepekaan tes berpikir kreatif akuntansi dan waktu yang diperlukan untuk menyesaikan tes berpikir kreatif sudah efektif dan dapat digunakan. Namun, pada kategori tes berpikir kreatif hal ini tidak efektif dikarenakan untuk menjawab tes tersebut dibutuhkan kemampuan yang cukup mendalam dan diperlukan waktu yang lama untuk meneliti serta faktor-faktor lain yang tidakditeliti pada penelitian ini.

\section{KESIMPULAN DAN SARAN}

Berdasarkan analisis hasil capaian penelitian pengembangan tes berpikir kreatif, makaakan dikemukakan beberapa kesimpulan:s

1. Tes berpikir kreatif akuntansi yang dikembangkan telah divalidasi dan hasilnya dinyatakan valid oleh para ahli. Serta telah melalui serangkaian analisis data yaitu validasi, daya pembeda, tingkat kesukaran dan reliabilitas dan didapat hasil dengan kriteria baik. 
2. Hasil tesberpikir kreatif belum efektif dikarenakan $85 \%$ siswa tidak memperoleh nilai minimum rata-rata sebesar 60.

3. Ketercapaian atas sensitivitas tes berpikir kreatif dimana diperoleh hasil dengan rata-rata sebesar $\mathrm{S}=0.434$.Kriteria penilaian sensitif terhadap hasil belajar tes berpikir kreatif akuntansijika $\mathrm{S} \geq 0.30$.

4. Berdasarkan hasil respon siswa terhadap tes berpikir kreatif akuntansi diperoleh rata-rata respon siswa sebesar $71.85 \%$ dengankriteria kurang positif.

Berdasarkan hasil pengembangan tes berpikir kreatif akuntansi, maka memberikan beberapa hal yang penting untukdiperhatikan. Berikut saran-saran yang dapat diberikan:

1. Tes berpikir kreatif yang dikembangkan belum efektif, sehingga siswa memerlukan kemampuan yang lebih dari biasanya dalam menyelesaikan tes tersebut.

2. Tes berpikir kreatif akuntansi yang dikembangkan peneliti ini berpeluang besar untuk dapat dikembangkan lagi secara lebih luas, karena dalam penelitian ini uji coba masih dalam skala kecil sehingga kurang maksimal.

3. Tes berpikir kreatif akuntansi yang dikembangkan mesih perlu diujicobakan secara lebih luas lagi pada sekolah lain agar diperoleh tes yang berkualitas.

\section{DAFTAR PUSTAKA}

Arikunto, Suharsimi. 2009. Dasar-Dasar Evaluasi Pendidikan. Jakarta:Bumi Aksara.

Horbi. 2010. Metode Penelitian Pengembangan Aplikasi Pada Penelitian Pendidikan Matematika. Jember: Pena Salsabila.

Lasiman, Rustam, Agus Suprijanto, Suhaila.2016.Pengembangan Butir Soal Tes Hasil Belajar

Siswa di SDN 2 Kelapa Tujuh di Kecamatan Kotabumi Selatan Kabupaten Lampung

Utara.Duta Palapa: Jurnal Keguruan dan Kependidikan. 1(2):10-18.

Munandar. 2009. Pengembangan Kreativitas Anak Berbakat. Jakarta:Rineka Cipta.

Sinaga, Bornok, 2007. Pengembangan Model Pembelajaran Matematika Berdasarkan Masalah

Berbasis Budaya Batak (PBM-B3). Disertasi:Universitas Negeri Surabaya.

Siswono, Tatag Yuli Eko. 2006. Implementasi Teori tentang Tingkat Berpikir Kreatif dalam

Matematika. Seminar Konferensi Nasional Matematika XIII dan Kongres Himpunan

Matematika Indonesia (pp.1-16). Semarang: FMIPA Universitas Negeri Semarang.

Sudjana, Nana. 1990. Teori-teori Belajar Untuk Pengajaran. Bandung: Fakultas Ekonomi UI.

Sugiyono. 2010. Metode Penelitian Pendidikan Pendekatan Kuantatif, Kualitataif, dan R\&D.

Bandung:Alfabeta.

Trianto. 2010. Mendesain Model Pembelajaran Inovatif Progresif. Jakarta:Kencana. 